\title{
18- Ortaokul öğrencilerinin okuma alışkanlığına ilişkin Türkçe öğretmenlerinin görüşleri
}

\author{
Fatime KIRS1
}

\section{İsmail KİNAY²}

APA: Kırs, F. \& Kinay, İ. (2022). Ortaokul öğrencilerinin okuma alışkanlığına ilişkin Türkçe öğretmenlerinin görüssleri. RumeliDE Dil ve Edebiyat Araștırmaları Dergisi, (26), 322-349. DOI: 10.29000/rumelide.1073930.

\section{$\ddot{O} \mathbf{z}$}

Okuma sevgisi ve alışkanlığının öğrencilere kazandırılmasında okuma alışkanlığı için kritik bir dönem olan ilköğretim yılları ve bu kademelerdeki ders veren Türkçe öğretmenlerinin rolleri gün geçtikçe önem kazanmaktadır. Bu araştırmanın amacı, ortaokul öğrencilerinin okuma alışkanlığını Türkçe öğretmenlerinin görüşleri doğrultusunda incelemektir. Bu kapsamda ortaokul öğrencilerin okuma alışkanlığını derinlemesine incelemek amacıyla, bu çalışmada nitel araştırma yöntemi ve bu yönteme uygun Olgubilim (fenomenoloji) araştırma deseni kullanılmıştır. Araştırmanın çalışma grubunu, amaçlı örnekleme yöntemlerinden ölçüt örnekleme göre belirlenen 19 Türkçe öğretmeni oluşturmuştur. Araştırma verilerini toplamak için nitel araştırma veri toplama tekniklerinden olan yarı yapılandırılmış görüşme formu kullanılmıştır. Görüşme sonucu elde edilen verilerin analizinde nitel veri analiz yöntemlerinden içerik analizi tekniği kullanılmıştır. Bu araştırmadan ulaşılan sonuçlara göre; ortaokul öğrencilerinin okuma alışkanlığı zayıf düzeydedir. Ebeveynlerin eğitim düzeylerinin yüksek olması öğrencilerin okuma alışkanlığını arttıran bir faktördür. Ekonomik yönden iyi düzeyde olan ebeveynlerin çocukları, diğerlerine kıyasla daha çok okuma alışkanlığına sahiptir. Öğrencilerin okuma alışkanlığına sahip olmalarının önünde engel unsurlar olarak en fazla televizyon izleme ve teknolojik iletişim araçları görülmüştür. Öğrencilerinin okuma alışkanlığı kazanmasında etkili unsurlar olarak, büyük çoğunlukla aile, öğretmen ve arkadaşlar ön plana çıkmıştır. Araştırmaya katılan Türkçe öğretmenlerinin tümü, ortaokul öğrencilerinin okuma alışkanlıkları ile akademik başarıları arasında doğru orantılı bir ilişki olduğu yönünde görüş bildirmişlerdir. Öğrencilere okuma alışkanlığını kazandırmaya yönelik Türkçe öğretmenleri, en fazla okullara ardından öğretmenlere ve ailelere önerilerde bulunmuşlardır.

Anahtar kelimeler: Okuma alışkanlığı, dil, Türkçe öğretmeni, öğrenci, ortaokul

\section{The opinions of Turkish language teachers on the reading habits of secondary school students}

\footnotetext{
Abstract

Primary school years, which is a critical period for reading habits, in gaining the love and habit of reading to students and the roles of Turkısh language teacher who teach at these levels are gaining importance day by day. The purpose of this research is to examine the reading habits of secondary school students in line with the opinions of Turkısh language teacher. In this sense, in order to

Doktora, Dicle Üniversitesi Eğitim Bilimleri Enstitüsü, Eğitim Programları ve Öğretim ABD (Diyarbakır, Türkiye), fatimekirs33@gmail.com, ORCID ID: 0000-0002-9469-6824 [Araștırma makalesi, Makale kaytt tarihi: 02.12.2021-kabul tarihi: 20.02.2022; DOI: 10.29000/rumelide.1073930]

2 Doç Dr., Dicle Üniversitesi, Ziya Gökalp Eğitim Fakültesi, Eğitim Bilimleri Bölümü (Diyarbakır, Türkiye), ismailkinay84@gmail.com, ORCID ID: 0000-0001-8963-8411

Adres $\mid$ Address

RumeliDE Dil ve Edebiyat Araştırmaları Dergisi Osmanağa Mahallesi, Mürver Çiçeği Sokak, No:14/8 Kadıköy - İSTANBUL / TÜRKIYE 34714 e-posta: editor@rumelide.com tel: +90 5057958124, +902167730616

RumeliDE Journal of Language and Literature Studies

Osmanağa Mahallesi, Mürver Çiçeği Sokak, No:14/8

Kadıköy - ISTANBUL / TURKEY 34714

e-mail: editor@rumelide.com,

phone: +90 5057958124, +90 2167730616
} 
examine the reading habits of secondary school students in depth, qualitative research method and phenomenology research design suitable for this method were used in this study. The study group of the research consisted of 19 Turkısh language teacher who were determined according to criterion sampling methods, one of the purposive sampling methods. To collect the research, it was carried out using a semi-structured interview form, which is one of the qualitative research techniques. The content analysis technique, one of the qualitative data analysis methods, was used in the analysis of the data obtained as a result of the interviews. According to the results of this survey; the reading habits of secondary school students are at a weak level. The high level of education of parents is a factor that increases students reading habits. Children of economically well-off parents have more reading habits than others. Watching television and technological communication tools were seen as the obstacles to the students reading habits. Mostly; family, teachers and friends came to the fore as effective factors in gaining reading habits of students. All of the Turkısh language teacher participating in the study stated that there is a direct proportional relationship between the reading habits of secondary school students and their academic success. Turkısh language teacher made suggestions mostly to schools, then to teachers and families, in order to help students gain the habit of reading.

Keywords: Reading habit, language, Turkısh language teacher, student, secondary school

\section{Giriş}

İnsanlık yaratılışından itibaren hissettiği duyguları, düşünceleri, gördüğü her şeyi başkalarına aktarmaya, kendini ifade etmeye yönelik bir çaba içinde olagelmiştir. Bu çaba neticesi ortaya çıkan dil, bir iletişim aracı olarak ön plana çıkmıştır. Böylece, insanoğlunu diğer canlı varlıklardan üstün kılan önemli vasıf olarak dil, ona çevresindekilerle iletişim kurma olanağı sağlamıştır. Tarihi süreçte ilkin sözlü olarak ifade edilen dil, belirli anlam ve göstergelerden oluşan dilsel sembollerin kullanılması ihtiyacını doğurmuştur. Bu ihtiyaçtan doğan yazının kullanılmasıyla başlayan yeni süreçte ise, yüzyllar boyu insanlığın sahip olduğu bilgi ve tecrübeler bu dilsel sembollerin oluşturduğu sözcükler, sözcüklerin oluşturduğu tümceler vasıtasıyla kalıcı hale gelmiştir. Yazının milat olduğu bu süreçte insanoğlu bu yazılı sembolleri anlamlandırmaya, dolayısıyla okumayı öğrenmeye çalışmıştır. Bununla beraber dinleme, konuşma, yazma ve okuma olarak dört temel dil becerisi üzerine bina edilen dil, toplumsal yaşayışta bireyin çeşitli gereksinimlerinin yanında bilgiye ve öğrenmeye dayalı gereksinimlerinin de karşılanması için sürekli bir gelişim içinde olmuştur.

Günümüze dek gelen toplumlar ve kültürler arasında, okumanın gelişimi, ayrılmaz bir şekilde dilin gelişimiyle ilişkilendirilmiştir. Zira hem okuma hem de dil, iletişim amacıyla gelişir ve okuma ile dilin geliştiği bağlam temelde sosyal bir bağlamdır. Bu bağlamda bir sanat olarak okuma, bir olgunluğun kazanılması, uygar dünyanın gündelik olaylarının, kültürel, politik, ekonomik gelişmelerinin takip edilebilmesi için temeli sağlam bir anadili öğrenimini gerekli kılmaktadır (Emin, 2003:8; Farran, 2010:5).

Halk arasında kullanılagelen mecazi ve çağrışım anlamları göz önüne alındı̆̆ında, onlarca farklı anlama gelebilecek okuma kavramı, basılı, yazılı basit metinleri okuyabilmek şeklindeki ilk anlamı dahil, çok farklı düzeyde becerileri ifade etmektedir. Ancak Türkçe'de bu kelimeye sınırlarını kesin olarak çizmenin zor olduğu çok sayıda anlam yüklenmiştir. Bu anlamlara şöyle bir bakılacak olursa; kişi, muhatabının açıkça dile getirmediklerini "niyetinden okur", "yüzünden okur", "hâl dilinden okur", "gözlerinden okur", söylediklerinin "satır aralarından okur" ve bu kişilerin "içini okur", "ciğerini okur", "kalbini okur",

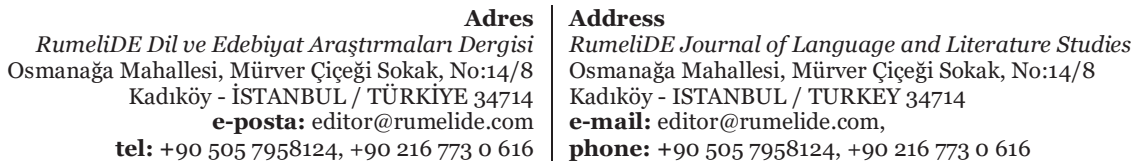


"mektubunu dışından okur". Muhatabının ne söylediğini duymadığı ya da anlamadığı durumlarda onun "dudağını okur", bir konuyla ilgili iyi seviyede bilgi sahibi olan kişi ise o konuyu "su gibi okur" (Özbay \& Bahar, 2012:159; Kantaş, 2013:188-190). Bu çalışmada okuma teriminin basıll, yazılı basit metinleri okuyabilmek şeklindeki ilk anlamı kastedilmektedir.

Anlam oluşturmak ya da türetmek için sembollerin kodunu çözmenin karmaşık bir bilişsel süreci olarak tanımlanan okuma (Sheeba \& Mohd, 2018:1), aynı zamanda yazlları keşfetme, anlama ve bilgileri zihinsel olarak yapılandırma yazının anlamına gönüllü katkı yapma sürecidir. Bu bakımdan okuma, anlam üretmeye yönelik bir test etme uygulamasıdır. Dolayısıyla, birey ön bilgileriyle yazının anlamını bulmakta ve bu anlamları birleştirerek yeni anlamlar oluşturmaktadır. Bu bağlamda okuma pratiğinin temelinde bireyin gelişimi, bilgi dağarcığının artması ve zenginliği ön plandadır (Johnson, 2008:3; Güneş, 2016:2; Ülger, 2015; 20). Bu minvalde dinleme, okuma, yazma ve konuşma olmak üzere birbirini tamamlayan dört beceriden müteşekkil dil becerileri arasında yer alan okumanın, insan hayatındaki önemli etkinliklerden biri olduğu söylenebilir. İnsanlar okuma vasıtasıyla, bu küreselleşme çağında zihinlerini zenginleştiren birçok bilgi edinebilmektedirler. Bu bakımdan okuma ve diğer okuryazarlık becerilerinin önemi günümüz toplumunda geniş çapta kabul görmektedir.

Okuma alışkanlığı, kişinin çok fazla düşünme sürecine veya tekrar eden bir faaliyete ihtiyaç duymadan, kendisi tarafından düzenli ve sürekli olarak yapılan ve bunun sonucunda alışkanlık haline gelen davranışıdır. Bu bağlamda okuma alışkanlığını, okumayı öğrendikten sonra bunu isteyerek, zevk alarak sürdürme eylemi şeklinde tanımlamak doğru olacaktır. Okuma alışkanlığı bireye sözlü ve yazılı olarak kendini iyi bir biçimde ifade edebilme, kolay iletişim kurabilme, doğru bir bakış sahibi olabilme, doğru anlayarak yorumlayabilme gibi pek çok becerileri kazandırmaktadır. Zira okuma alışkanlığı kazanan birey; okuduklarını çevresindekilerle paylaşır, okudukları üzerinde düşünür, okuduklarını yorumlayabilir, okuyarak öğrendiklerini hayatına yansıtabilir ve nihayetinde okuyacağı materyali kendi kendine seçebilir duruma gelebilmektedir. Bu bakımdan okuma alışkanlı̆̆ kazanmak, insana hayatın neredeyse tüm sefaletlerinden bir sı̆̆ınak yapmaktır (Noor, 2011:2; Suhana \& Haryudin, 2017:58; Durukan \& Arslan, 2018:146-147; Çakmak ve Yılmaz, 2009; 492-497; Çelik, 2020: 1027-1028). Bu nedenlerle, öğrencilerin okumaya yaşamlarının bir parçası olarak ihtiyaçları olduğunun farkına varmaları ve okuma alışkanlığına değer vermeleri sağlanmalıdır.

Toplumsal gelişimde, bireyin kültürel çevreye uyumunda, edindiği bilgi ve deneyim ile geleceğe daha iyi hazırlanabilmesinde önemli rolü olan okuma alışkanlığı bireylerde küçük yaşlarda kazanılmaya başlanan bir davranıştır (Batur, Erkek, Kaplan \& Ercan, 2017:44; Çakmak \& Yılmaz, 2009:492). Okul öncesi eğitim aşamasında öğrencinin gelişim alanları tam olarak tamamlanamaması nedeniyle okuma alı̧kanlığı süreci görsel okuma ile başlamaktadır. İlköğretim dönemi ve sonrasında ise okuma eylemi bağımsız bir beceri olarak kazanılabilmektedir. Bu bakımdan okuma alışkanlığı hayatın her döneminde kazanılabilir olsa da bu alışkanlığın kolay kazanıldığı dönem ilköğretim ve ortaöğretim yıllarıdır. Zira bu ylllar çocuğun okul ve aile etkileşiminin çok yoğun olduğu yıllardır (Sayır, 2018:8).

Okuma alışkanlığına sahip olma, kişisel anlamda öğrencilere günlük ve akademik yaşamında, sosyal olarak ise toplumsal rollerin doğru bir şekilde yerine getirebilmesinde her geçen gün artan bir gereklilik halini almaktadır (Mut \& Gelişli, 2021: 93). Fakat okuma eylemi, bu denli önemli olmasına karşın toplumumuzda gereken ilgi ve ehemmiyeti görememektedir (Arıc1, 2015:2; Şahin, Sevim, Gücüyeter \& Şahin, 2009: 3). Ancak son yıllarda birçok araştırmaya konu olan ve özellikle dünyayı olduğu gibi Türkiye'yi de etkisi altına Covid 19 salgını nedeniyle yaşanan kapanma ve öğrencilerin uzaktan eğitimi sürecinde üzerinde önemle durulan okuma alışkanlığı, dikkatlerin bu konuya daha fazla yoğunlaşmasına

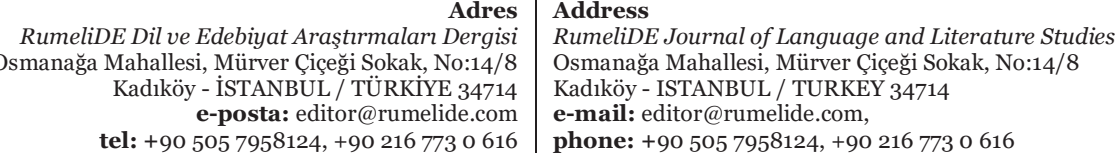


yol açtığı söylenebilir. Alan yazın incelendiğinde okuma alışkanlığına ilişkin yapılmış olan hem yurt içi hem yurt dışında çok sayıda farklı araştırmalara rastlamak mümkündür. Yurt içi yapılan çalışmalar arasında örgün eğitim kademesinde yer alan ilkokul öğrencilerinin okuma alışkanlığını belirlemeye yönelik, Yavaş (2013), Taş (2018), Aksaçlığlu ve Yılmaz (2007); ortaokul öğrencilerinin okuma alışkanlığını belirlemeye yönelik Deniz (2015), İşcan, Arıkan ve Küçükaydın (2013), Davarcı (2013), Deniz (2017), Karadayı (2019), Mete (2012), Öztürk ve Aksoy (2016) ve ortaöğretim öğrencilerinin okuma alışkanlığını belirlemeye yönelik Kaynar (2007), Gündoğdu, Barata ve Çelebi (2016), Güney, Aytan, Kaygana ve Şahin (2014), Taşkesenlioğlu (2016), Can, Türkyılmaz ve Karadeniz (2010) olmak üzere bazı araştırma sonuçlarına ulaşılmaktadır. Yurt dışında yapılan çalışmalardan Sivasubramanian ve Gomathi, (2019), Le, Tran, Trinh, Nguyen, Nguyen, Vuong, Vu, Bui, Vuong, Hoang, Nguyen, Ho ve Vuong, (2019), Anish ve Joseph (2017), Rosli, Razali, Zamil, Noor ve Baharuddin (2017) ortaokul öğrencilerinin okuma alışkanlığını belirlemeye yönelik araştırmalar yapmışlardır. Ancak çoğunlukla nicel yönteme dayalı farklı sonuçlara ulaşılan bu araştırmalar ve okuma alışkanlığının küçük yaşlarda kazanıldığı göz önünde tutulduğunda ilköğretim öğrencilerinin okuma alışkanlığına ilişkin daha çok çalışmaya ve dolayısıyla farklı araştırma yöntemli daha çok veriye ihtiyaç olduğu düşünülmektedir

21.yüzyılda eğitim sistemlerinin temel amaçları arasında, içinde bulunulan bilgi, iletişim ve teknolojik gelişmelerin getirdiği bir gereklilik olarak temel dil becerilerindeki yetkinliklerin daha üst düzeye çıarılması yer almaktadır. Dolayısıyla mevcut öğretim programlarının üzerine yapılandırıldığı dört temel dil becerisinden biri olan okuma becerisine ilişkin yetkinlikler gün geçtikçe önem kazanmaktadır. Bu bağlamda Sever (2003:28), öğretimin ileriki basamaklarında öğrencilerin edebiyatımızın klasik ve çağdaş eserlerini okuması, bu eserlerle etkili bir iletişime girmesi için Türkçe öğretiminin ilköğretim birinci sınıftan başlayıp sekizinci sınıfın sonuna dek etkili ve verimli kılınmasıyla mümkün olduğunu ifade etmektedir. Zira öğrencilerin bilişsel, sosyal ve duygusal yönden gelişimini sağlamak ancak onların etkili iletişim kurabilmeleri, dil becerilerini geliştirebilmeleri ile mümkündür (Belet-Boyacı \& GünerÖzer, 2019:712). Bu çerçevede Milli Eğitim Bakanlı̆̆ tarafından son olarak yayımlanan 2019 Türkçe Dersi Öğretim Programının (İlkokul ve Ortaokul 1, 2, 3, 4, 5, 6, 7 ve 8. Sınıflar) özel amaçları kısmında, öğrencilerin Türkçe sevgisiyle, istek duyarak okuma ve yazma alışkanlığı edinmelerini sağlamak için programın bilgi, beceri ve değerleri içeren bir bütünlük içinde yapılandırılmış olduğu ifade edilmektedir. Ayrıca programın uygulanması sürecinde her sınıf düzeyinde işlenmesi öngörülen sekiz tema içinde yer alan “Okuma Kültürü” teması içinde okuma alışkanlı̆̆ı konusu önerilmektedir (MEB, 2019:8-15).

Bireyin okuma alışkanlığı kazanmasında en önemli kurum ailedir. Bireyler, ailesinden gördüğü şekilde, olaylara yaklaşmakta ve kararlar almaktadır. Dolayısıyla, kendilerine zaman ayırarak kitap okuyan ebeveynler, çocuklarına kitap okumanın zevkli bir uğraş olduğu mesajını vermektedirler. Bu bilince sahip ailelerin çocuklarına model olması, aileye düşen önemli bir sorumluluktur. Zira ebeveynlerin idealler bağlamında işlevi belirleyicidir ve eğer kendileri okurlarsa, çocukları da düzenli okuma becerisini kolayca kazanabilmektedir (Bamberger, 1975:33; Durukan \& Arslan, 2018:148; Okur, 2013:18; Ylldız, 2018:186-187). Bu nedenle öğrencilere okul ortamındaki öğrenmelerinde büyük katkısı olan okuma becerilerinin kazandırılması ve bilinçli okurların yetiştirilmesi; öğrencinin ilgisine, yeteneğine, ailede okumaya yönelik tutum ve davranışlara, okumaya uygun bir ortam oluşturulmasına bağlıdır. Bunların yanı sıra okullarda verilen eğitim sistemi, bu sistemi uygulayan öğretmenlerin tutum ve davranışları, uygulama sürecinde aileler, okul ve sınıf kütüphanelerinin işlevselliği, çevresel faktörler gibi birçok etken söz konusudur (Çakmak ve Yllmaz, 2009;492-497; Çelik, 2020: 1027-1028). Bu etkenlerin başında gelen öğretmenlere, bilhassa Türkçe öğretmenlerine okuma becerisinin alışkanlığa dönüştürülebilmesinde büyük görevler düşmektedir. Zira öğrencinin örnek metinlerle bu beceriyi kullanabilecek düzeye ulaşması, daha sonra ise düzeyine, ilgisine ve ihtiyaçlarına göre kitap belirleyerek

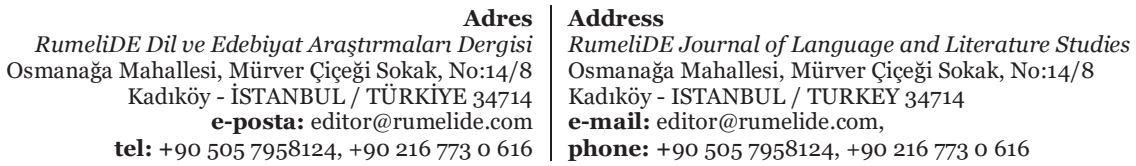


okuyabilmesi bir gereklilik halini almaktadır (Batur, Erkek, Kaplan \& Ercan, 2017:44; Özden, 2018:303; Maden \& Maden, 2018:3). Bu amaçla öğretmenin, Türkçe derslerinde yapacağı çeşitli çalışmalar, öğrencilerin önce kitap okuma alışkanlığı ve zevki kazanmalarını, sonrasında değerli eserleri kendi başlarına arayıp bularak okuduklarını değerlendirebilecek düzeye gelmelerini sağlayacaktır (Alperen, 1990:12). Bu bağlamda, Milli Ĕ̆itim Bakanlığı tarafından yeni bir yaklaşımla geliştirilen 2006 Türkçe Dersi Öğretim Programı’nda "Programın Uygulanmasında Öğretmenin Rolü” başlığı altında öğretmenler için belirlenen öğrencilerin seviyelerine uygun kitaplardan oluşan bir liste düzenler ve listeyi günceller, kazanımına yer verilmiştir. Aynı öğretim programında "Okuma Alışkanlığının Kazandırılması" başlı̆̆ı altında ise, öğrenme sürecinde okumanın payının büyük olduğu, okuma alışkanlığı ve sevgisi kazanmış bir öğrencinin tüm derslerinde başarılı olacağı ifade edilerek her öğrenciye okuma alışkanlığının kazandırılabilmesi için öğretmenin, öğrenciyi ilgisini çekebilecek türde kitaplar okumaya yönlendirmesi, velilerle iş birliği yaparak öğrencilere evde de okuyabilecekleri kitaplar önermesi tavsiye edilmiştir (MEB, 2006: 55- 205). Bu bakımdan okuma sevgisi ve alışkanlığının öğrencilere kazandırılmasında okuma alışkanlığı için kritik dönem olan ilköğretim yılları ve bu kademelerdeki ders veren Türkçe öğretmenlerinin rolleri gün geçtikçe önem kazanmaktadır. Dolayısıyla, ortaokul kademesinde görev alan öğretmenlerin gözüyle öğrencilerin okuma alışkanlığının bir değerlendirilmesinin yapılması mevcut araştırmalara yeni bir boyut ve bakış açısı kazandıracak veriler sağlaması yönüyle bir ihtiyaç olarak görülmektedir. Bu çerçevede ortaokul öğrencilerin okuma alışkanlığına yönelik elde edilecek öğretmen görüşleriyle alan araştırmacılarına, eğitimcilere, okuma alışkanlığını tüm topluma yaymayı hedefleyen öğretim programlarına katkı sağlayacak yeni verilerin sunulması bu çalışmanın çıkış gayesini oluşturmaktadır.

\section{Araştırmanın amacı}

Bu çalışmanın amacı, ortaokul öğrencilerinin okuma alışkanlığını Türkçe öğretmenlerinin görüşleri açısından nitel bir yaklaşımla incelemektir. Bu amaç doğrultusunda aşağıdaki sorulara yanıt aranmıştır:

1. Türkçe öğretmenlerin ortaokul öğrencilerinin okuma alışkanlığına sahip olup olmadığına ilişkin görüşleri nelerdir?

2. Türkçe öğretmenlerin ortaokul öğrencilerinin okuma alışkanlıklarında anne ve babalarının eğitim ve ekonomik durumlarının rolü hakkındaki görüşleri nelerdir?

3. Türkçe öğretmenlerine göre, ortaokul öğrencilerinin okuma alışkanlığına sahip olmasına engel olan unsurlar nelerdir?

4. Türkçe öğretmenlerine göre, ortaokul öğrencilerinin okuma alışkanlığı kazanmasında rol oynayan etmenler nelerdir?

5. Türkçe öğretmenlerinin ortaokul öğrencilerinin okuma alışkanlıkları ile akademik başarıları arasında bir ilişki olup olmadığına ve bunun nedenine ilişkin görüşleri nelerdir?

6. Türkçe öğretmenlerinin görüşlerine göre, ortaokul öğrencilerine okuma alışkanlığı kazandırılmasına yönelik yapılabilecek çalışmalar nelerdir?

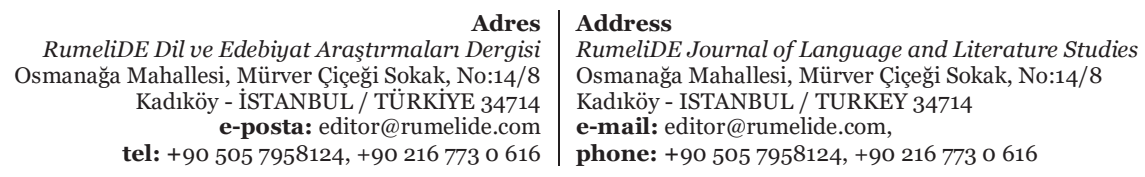




\section{Yöntem}

\subsection{Araştırma deseni}

Türkçe öğretmenlerinin görüşleri açısından ortaokul öğrencilerin okuma alışkanlığını derinlemesine irdelemek amacıyla, bu çalışma nitel araştırma yöntemine göre gerçekleştirilmiştir. Bu araştırmada, katılımcıların araştırmaya konu olan olguya yönelik yaşadıkları deneyimlerini anlamlandırmak için nitel araştırma yaklaşımına uygun araştırma deseni olan Olgubilim (fenomenoloji) kullanılmıştır. Olgubilim (fenomenoloji), bir fenomenin bireylerin veya belli bir grubun deneyimleri açısından tanımlanmasıdır (Christensen, Johnson \& Turner, 2015: 409). Olgubilim bireye tümüyle yabancı olmayan, aynı zamanda tam olarak anlamını kavrayamadığı olguları araştırmayı amaçlayan çalışmalar için uygun bir araştırma zemini oluşturmaktadır (Yıldırım \& Şimşek, 2018:69). Bu nedenle Türkçe öğretmenlerinin bireysel deneyimlerinden yararlanarak ortaokul öğrencilerinin okuma alışkanlığı incelenmeye çalışmıştır.

\section{2. Çalışma grubu}

Araştırmanın çalışma grubunu 2021-2022 eğitim öğretim yllının 1. döneminde, Batman il merkezinde yer alan devlet ortaokullarında görev yapan 19 Türkçe öğretmeni oluşturmuştur. Araştırmanın çalışma grubu amaçlı örnekleme yöntemlerinden ölçüt örnekleme göre belirlenmiştir. Ölçüt örneklemede araştırmaya konu olan gözlem birimleri, belli niteliklere sahip kişiler, olaylar, nesneler ya da durumlardan oluşturulduğunda, örneklem için belirli ölçütü karşlayan birimler örnekleme alınmaktadır (Büyüköztürk, Kılıç-Çakmak, Akgün, Karadeniz ve Demirel, 2013:91). Bu bağlamda ölçüt örnekleme yöntemindeki temel anlayış, önceden belirlenen birtakım ölçütleri karşılayan tüm durumları çalışma firsatı vermesidir (Yıldırım ve Şimşek, 2016:123). Bu araştırmada ortaokul öğrencilerinin okuma alışkanlığına ilişkin Türkçe öğretmenlerinin yaşadıkları deneyimlerine dayalı görüşlerinin incelenmesi amaçlandığından araştırmaya dâhil edilen öğretmenlerin belirli bir mesleki deneyimine sahip olmasına dikkat edilmiştir. Bu nedenle, çalışma grubu için belirlenen ölçüt gereği; ortaokul kademesinde Türkçe öğretmeni olarak 10 yll ve üstü hizmet yılını dolduran kadrolu 8 kadın, 11 erkek olmak üzere toplamda 19 Türkçe öğretmeni araştırmanın örneklemini oluşturmuştur.

\subsection{Veri toplama aracı}

Araştırma verilerini toplamak için nitel araştırma veri toplama tekniklerinden olan yarı yapılandırılmış görüşme formu kullanılmıştır. Olgubilim araştırmalarında başlıca veri toplama aracı görüşmedir. Zira olgulara ilişkin yaşantı ve anlamları ortaya koyma için görüşmenin araştırmacıya sunduğu etkileşim, esneklik ve sondalar yoluyla irdeleme özelliklerinin kullanılması gerekmektedir (Yıldırım \& Şimşek, 2018:71) Bunun için belirlenen çalışma konusuna ilişkin alan yazın kaynaklar titiz ve dikkatli bir çalışma ile incelenmiştir. Bu inceleme sonucu çalışmanın amacına ve alt amaçlarına uygun olarak yedi açık uçlu sorudan oluşan yarı yapılandırılmış görüşme formu araştırmacılar tarafindan hazırlanmıştır. Hazırlanan görüşme formunda bulunan açık uçlu sorular Türkçe Eğitimi alanında 1, Türk Dili ve Edebiyatı alanında 1, Eğitim Programları ve Öğretim alanında ise 4 olmak üzere altı akademisyen tarafından incelenmiştir. Uzmanların incelemeleri ve yapmış oldukları önerileri doğrultusunda altı olan soru sayısı binişikliği önleme ve yanıtlamayı kolaylaştırma amacıyla yediye çıkarılmıştır. Ayrıca üç sorunun ifade biçimi değiştirilerek daha özlü ve anlaşılır hale getirilmiştir. Uzmanların görüşlerinden istifade edilerek tekrar düzenlenen yarı yapılandırılmış görüşme formu ile çalışma grubu dışında tutulan 4 Türkçe öğretmenin katılımcı olduğu bir ön uygulama gerçekleştirilmiştir. Ön uygulamaya katılan Türkçe öğretmenlerinin görüşleri araştırmada değerlendirme kapsamına alınmamıştır. Uygulama

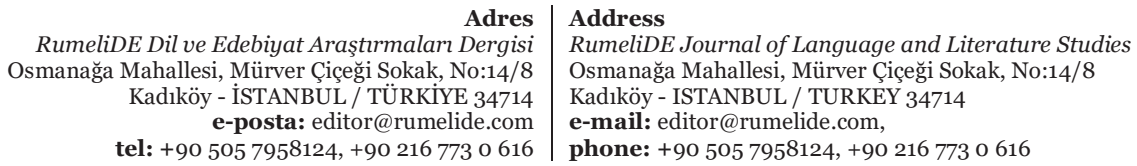


sonucunda verilen cevaplardan yola çıkılarak anlaşılmayan veya işlemeyen herhangi bir soru olmadığı belirlenmiş ve bu nedenle sorularda yeni bir düzenlemeye gerek duyulmamıştır. Böylece tüm bu süreçlerle yarı yapılandırılmış görüşme formuna son şekli verilmiştir. Bunun akabinde görüşme formunun Etik Kurul Onayı için Dicle Üniversitesi Sosyal ve Beşeri Bilimler Etik Kurulu'na başvuru yapılmış olup 28/09/2021 tarihinde gerekli onay alınmıştır. Yarı yapılandırılmış görüşme formu aşağıda yer alan açık uçlu yedi sorudan oluşmaktadır:

1. Bir Türkçe öğretmeni olarak ortaokul öğrencilerinizin okuma alışkanlığına sahip olma durumuna ilişkin görüşleriniz nelerdir?

2. Ortaokul öğrencilerinizin okuma alışkanlıklarında anne ve babalarının eğitim durumlarının rolü hakkındaki görüşlerinizi bizimle paylaşır mısınız?

3. Ortaokul öğrencilerinizin okuma alışkanlıklarında ailenin ekonomik durumunun rolüne ilişkin görüşlerinizden bahseder misiniz?

4. Size göre, ortaokul öğrencilerinizin okuma alışkanlığına engel olan unsurlar nelerdir?

5. Size göre, ortaokul öğrencilerinizin okuma alışkanlığı kazanmasında rol oynayan etmenler nelerdir?

6. Ortaokul öğrencilerinizin okuma alışkanlıkları ile akademik başarıları arasında bir ilişki olduğunu düşünüyor musunuz? Nedenini açıklar mısınız?

7. Size göre, ortaokul öğrencilerine okuma alışkanlığı kazandırılmasına yönelik yapılabilecek çalışmalar nelerdir?

\subsection{Verilerin toplanması}

$\mathrm{Bu}$ araştırmanın verileri araştırmacılar tarafindan Batman İl Milli Eğitim Müdürlüğünden 07/10/2021 tarihli alınan araştırma izniyle, 10/10/2021 ile 03/11/2021 tarihleri arasında nitel araştırma tekniklerinden yarı yapılandırılmış görüşme tekniği ile yüz yüze toplanmıştır. Yarı yapılandırılmış görüşme tekniği, hem sabit seçenekli cevaplamayı hem de araştırılan konuda derinlemesine çalışmayı birleştirir (Büyüköztürk ve diğ., 2013:152). Bu teknik, araştırmacı tarafından önceden hazırlanan sorular yoluyla, görüşme esnasında araştırmaya konu olan kişilere kısmi esneklik sağlayarak söz konusu görüşme sorularının tekrar düzenlenmesine ve tartışılmasına olanak sağlamaktadır (Ekiz, 2017:63). Çalışma kapsamında Türkçe öğretmenleriyle yapılacak görüşmelerin yer ve zaman planlamasının yapılabilmesi için araştırmacı tarafından okullardan randevu alınmıştır. Yapılan görüşmelerde gönüllülük ilkesine dayalı olarak katılımcılara yedi açık uçlu soru sorulmuş, verilen yanıtlar doğrultusunda yer yer ek sorular kullanılmıştır. Görüşme formuna katılımcıların verdikleri yanıtlar yazılarak kaydedilmiştir. Görüşmelerin her birinin süresi yaklaşı 40 dakika olarak gerçekleştirilmiştir. Uygulama araştırmacının kontrolünde gerçekleştirilmiş olup araştırmanın güvenilirliği için, araştırma soruları her katılımcıya aynı üslup, ifade biçimi ve sırayla sorulmuştur. Böylece katılımcıların soruları herhangi yönlendirme yapılmaksızın yanıtlamaları sağlanmıştır.

\subsection{Verilerin analizi}

Geliştirilen yarı yapılandırılmış görüşme formu 1. araştırmacı tarafından bizzat 19 katılımcıya yüz yüze olarak uygulanmıştır. Katılımcıların verdikleri yanıtlardaki bazı ifade tekrarları ve anlatım bozuklukları 
kendilerinden izin alınarak düzeltilmiştir. Görüşme sonucu elde edilen verilerin analizinde nitel veri analiz yöntemlerinden içerik analizi tekniği kullanılmıştır. İçerik analizi ile toplanan verileri açıklayabilecek kavramlara ve ilişkilere ulaşmak amaçlanmaktadır. Bu kapsamda araştırmacılar, içerik analizi kullanarak verilerin tanımlamaya, veriler içinde saklı olabilecek gerçekleri gün yüzüne çıkarmaya çalışmaktadır. Bu analiz tekniğinde, birbirine benzeyen veriler, araştırmacılar tarafından belirli kavramlar ve temalar altında bir araya getirilerek bunları okuyucunun anlayabileceği bir şekilde düzenlenmesi ve yorumlanmasını içeren işlem basamakları uygulanmaktadır. Bu uygulama dört aşamadan oluşmaktadır: (1) Verilerin kodlanması, (2) temaların bulunması, (3) kodların ve temaların düzenlenmesi ve (4) bulguların tanımlanarak yorumlanması (Yıldırım ve Şimşek, 2016:242-243). Bu doğrultuda yapılan görüşmelerin ardından her bir soruya katılımcılar tarafindan verilen cevaplar, araştırmacılar tarafından tek tek ele mercek altına alınmış, ifade edilen cümlelerdeki anlamlar özetlenerek kodlanmıştır. Bu kodlara ve araştırma sorularına dayalı olarak temalar (kategoriler) oluşturulmuştur. Oluşturulan temalar düzenlenmiş, ardından araştırmacılar tarafından tanımlanarak yorumlanmıştır. Buna ilaven elde edilen veriler analiz edilirken çalışmanın güvenilirliğinin sağlanması amacıyla doğrudan alıntılar yapılmıştır. Bu çerçevede verilerin analizinde her bir öğretmene, "TÖ-1, TÖ2, TÖ-3... ” şeklinde harf ve numaralar kullanılarak bir kod ad verilmiştir.

Çalışmanın geçerliliğini sağlamak amacıyla katılımcıların görüşme formundaki görüşlerinde bir değişmenin olup olmadığını belirlemeye yönelik olarak görüşmeden 15 gün sonra katılımcı teyidi araştırmacı tarafından alınmıştır. Zira araştırılan olgu ve olaylar hakkında bütüncül bir bakış açısı oluşturulması için katılımcı teyidi, meslektaş teyidi gibi araştırmacının ulaştığı sonuçları teyit etmesine yarayacak bazı yöntemler gereklidir (Yıldırım ve Şimşek, 2016:269). Araştırmanın iç geçerliliğinin sağlamak için araştırmanın amacı, yöntemi, çalışma grubu ve bu grubun özellikleri, örnekleme yöntemi, verilerin toplanması, verilerin analiz süreci, bulguların yorumlanması ve sonuçlara ilişkin tüm işlem basamakları ayrıntılı olarak açıklanmıştır. Zira araştırmacı, çalışmanın iç geçerliliği için veri toplama süreçleri, verilerin analizi ve yorumlanması süreçlerinde tutarlı olmalı ve bu tutarlılığı nasıl sağladığını ortaya koymalıdır (Yıldırım ve Şimşek, 2016:271). Bu araştırmada güvenilirliği sağlamak için; Türkçe öğretmenlerinin görüşme sorularına verdiği yanıtlar iki araştırmacı tarafından birbirinden bağımsız biçimde ayrı ayrı incelenerek kodlanmıştır. Ardından her iki araştırmacının aynı görüşme verileri üzerinde yapmış olduğu kodlamalar karşılaştıılmıştır. Nitel araştırmalarda güvenilirlik kontrolü, veriler üzerinde birden çok araştırmacının yaptığı kodlamalar arasındaki tutarlılık olduğundan (Creswell, 2017:200); yapılan karşılaştırma sonucu her iki araştırmacının yaptığı kodlamalardaki benzerlik ve farklılıklar belirlenmiştir. Bu kapsamda Miles ve Huberman'ın (1994:64) önerdiği güvenilirlik formülü olan Güvenilirlik = Görüş Birliği / (Görüş Birliği + Görüşs Ayrıllı̆̆l) 100 kullanılmıştır. Bu formül doğrultusunda her iki araştırmacının aynı kodu kullandığı ifadeler "görüş birliği”, farklı kodu kullandığı ifadeler "görüş ayrılığı" olarak kabul edilmiştir. Bu kapsamda kodlar ayrı ayrı incelenerek "görüş birliği" ve "görüş ayrıllğı" olan kodlar belirlenmiştir. Belirlenen kodlar düzenlenmiş ve her iki kodlama arası güvenilirlik hesaplaması söz konusu güvenilirlik formülü kullanılarak yapılmıştır. Yapılan güvenirlik hesaplaması sonucu kodlayıcılar arası görüş birliği diğer deyişle, araştırmanın güvenilirlik ortalaması \% 95,34 olarak bulunmuştur. Miles ve Huberman, (1994:64)'a göre, yapılan araştırmanın güvenilir kabul edilmesi için kodlayıcılar arası görüş birliğinde en az \% 80 oranı arandığından, mevcut araştırmanın güvenilir olduğu kabul edilmiştir. Ayrıca iki alan uzmanından analiz süreci sonunda yapılan kodlamaları ve öğretmen görüşlerini incelemeleri istenmiştir. İnceleme sonucunda, uzmanların büyük oranda görüş birliği sağlaması üzerine verilerin kodlama işlemi son şeklini almıştır. Araştırmanın güvenilirliğine ilişkin son olarak bulgular bölümünde, araştırma sonuçlarının gerçekçi olarak yansıtılması amacıyla Türkçe öğretmenlerin görüşlerinden seçilen bazı doğrudan alıntılara yer verilmiştir. 


\section{Bulgular}

Ortaokul öğrencilerinin okuma alışkanlığını Türkçe öğretmenlerinin görüşlerine dayalı olarak incelemeyi amaçlayan bu araştırmada çalışmanın alt amaçlarına uygun olarak bulgular oluşturulan temalar altında verilmiştir. Her temaya ait alt temalar ve kodlamalar tablolaştırılarak verilmiş olup katılımcı görüşlerinden doğrudan alıntılar yapılmıştır.

\section{Tema 1: Öğrencilerin okuma alışkanlı̆̆ı}

Bu tema altında araştırmanın birinci alt amacı olan Türkçe öğretmenlerinin ortaokul öğrencilerinin okuma alışkanlığına sahip olup olmadığına ilişkin görüşleri kodlanarak bir araya getirilmiştir. Türkçe öğretmenlerinin görüşleri neticesinde elde edilen alt temalar, kodlamalar ve frekans değerleri aşağıda Tablo 1'de verilmiştir.

Tablo 1. Öğrencilerin okuma alışkanlığı ana temasına ait alt temalar ve kodlar

\begin{tabular}{|c|c|c|}
\hline Alt Temalar & Kodlar & Frekans \\
\hline Okuma alışkanlığı düzeyi zayıf & $\begin{array}{l}\text { Sıkıntı (TÖ.3), düzey arttırma çalışmaları (TÖ.3), okuma } \\
\text { alışkanlığına sahip değil (TÖ.5, TÖ.10), düşüş (TÖ.6), } \\
\text { zayıf düzey (TÖ.6, TÖ.7), Pandeminin olumsuz etkisi } \\
\text { (TÖ.6, TÖ.7), okuma takibi (TÖ.6, TÖ.7), yetersiz (TÖ.9, } \\
\text { TÖ.18, TÖ.19), çok az (TÖ.19), zorlama olmadan } \\
\text { okuyanların okuma alışkanlığı yüzde yirmi seviyesinde } \\
\text { (TÖ.17), sıkılma (TÖ.15), zorunluluk (TÖ.15), okumanın } \\
\text { tadını almama (TÖ.11), okumayı angarya gören } \\
\text { öğrenciler (TÖ.11), büyük çoğunlukla yok (TÖ.14), } \\
\text { okumama (TÖ.16), bir türlü oturmama (TÖ.15), zorluk } \\
\text { (TÖ.17), rahatına düşkünlük (TÖ.17), sosyal medya } \\
\text { tercihi (TÖ.17). }\end{array}$ & $*_{2} 26$ \\
\hline Okuma alışkanlığı düzeyi orta & $\begin{array}{l}\text { Orta düzey (TÖ.1, TÖ.2, TÖ.12), arttırma çalışmaları, } \\
\text { (TÖ.2), teşvik (TÖ.2), merak (TÖ.2), okuma grubu } \\
\text { (TÖ.2), kontrol (TÖ.12), gözetim (TÖ.12), düzenli } \\
\text { okuma (TÖ.12), haftada bir kitap (TÖ.12). }\end{array}$ & 11 \\
\hline Okuma alışkanlığı düzeyi yüksek & Yüksek düzey (TÖ.4) & 1 \\
\hline
\end{tabular}

*Katılımcı öğretmenler öğrencilerin okuma alışkanlığına ilişkin birden fazla görüş ifade ettiklerinden elde edilen toplam frekans sayısı katılımcı öğretmen sayısından fazladır.

Yukarıda Tablo 1'de görüldüğü üzere, “Öğrencilerin Okuma Alışkanlığı” ana teması altında oluşturulan üç alt temaya ait kodlama ve frekans değerlerinde dikkat çekici şekilde Türkçe öğretmenlerinin derslerine girdikleri ortaokul öğrencilerinin okuma alışkanlığı düzeyinin zayıf olduğu yönündeki ifadeleri (f:26) yoğunluktadır. Buna karşın öğretmenlerin öğrencilerinin okuma alışkanlı̆̆ı düzeyini orta (f:11) ve yüksek (f:1) olarak niteledikleri görüşlerin son derece az kaldığı görülmektedir. Bu ifadelere ait kodlamalara bakıldığında ise, "yetersiz”, “okuma alışkanlığına sahip değil”, "Pandeminin olumsuz etkisi” ve "okuma takibi” ifadeleri öne çıktı̆̆ı görülmektedir. Tablo 1'de yer alan bu kodlamaları içeren öğretmen görüşlerinden bazı örnekler aşağıda verilmiştir:

"Bir Türkçe öğretmeni olarak üzülerek belirtmeliyim ki ortaokulun tüm kademelerinde öğrencilerimizin okuma alışkanlı̆̆ıa sahip olmadığını düşünüyorum.” (TÖ.1O)

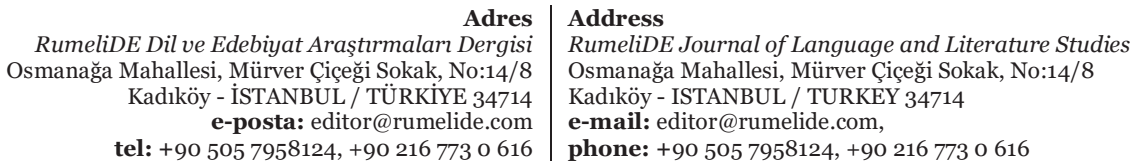


“Öğrencilerimin okuma alşkanlı̆̆ orta düzeyde. Bu düzeyi yükseltmek için birçok çalısma yapmaktayım. Kitap fuarlarına öğrencilerimi götürerek öğrencinin bizatihi kendisinin kitap seçmesini sağhyorum. Fuarda yazarlarla buluşturuyorum. Öğrencilerimin yazarlarla çekilmiş fotoğrafların okul panosuna asarak onları teşvik ediyorum." (TÖ.2)

"Ortaokul öğrencilerimizin çoğu kitap okuma alışkanlı̆̆na sahip değil. Tabii bu alışkanlı̆̆ın çok küçük yaşlarda başlaması gerekiyor. Çocuk kitap okumayı bir yük olarak görüyor.” (T.Ö. 5).

"Çocukların büyük bir kısmının okuma alş̧kanlığına sahip olduğunu gözlemledim. Bu alş̧kanlık ailede veya ilkokulda kazanılmış olabilir.”(TÖ:4).

"Zayıf düzeyde. Yaklaşık son iki yıldır yaşanan Pandemi nedeniyle bireysel takip azaldığı için okuma seviyesi daha da düştü.” (TÖ.7).

“Ortaokulda okuma alş̧kanlığı kazanmışöğrencilerin genellikle ilkokulda bu alş̧kanlığı kazandığımı görmekteyim. Daha sonradan bu alş̧kanlığ edinenler olsa da ekseriyet ilkokulda edinilmektedir. Biz Türkçe öğretmenlerinin okuma ile ilgili yaptığı çalışmaları önemseyen öğrenciler olurken aynı zamanda bunu bir angarya olarak görenler de var.” (TÖ.11).

"Çocuklardaki okuma alışkanhı̆ının bir türlü oturmadığı kanaatindeyim. Okumayı sadece okuldaki okuma saatinden ya da Türkçe öğretmeninin verdiği kitap ödevinden ibaret saydıkları için öğrenciler okuma alışkanhğımı kazanamıyor.” (TÖ. 16)

"Çocuklar okuma uğraşına pek girmiyor. Bu onlarn zorluyor. Zorluğa gelemiyorlar. Rahatlarma düşkün oluyorlar. Görsel ve kolay olan sosyal medyayı tercih ediyorlar.” (TÖ:15)

Türkçe öğretmenlerinin bu temaya ilişkin görüşleri incelendiğinde ortaokul öğrencilerinin okuma alışkanlığına sahip olmaları için kritik dönemin ilkokul dönemi olduğu vurgulanmaktadır. Buna ilaven Pandemi dönemi ile öğrenci takibinin yapılamamasının okuma alışkanlı̆̆ını olumsuz etkilediğini ifade etmişlerdir. Dolayısıyla öğrencilerde okuma alışkanlığının kazandırılmasında okulda yapılan çalışmaların bireysel takip ile ev ortamında da sürdürülmesi son derece etkilidir.

\section{Tema 2: Okuma alışkanlığında ebeveynin eğitim ve ekonomik düzeyinin rolü}

$\mathrm{Bu}$ tema başlı̆̆ı altında Türkçe öğretmenlerinin araştırmanın ikinci alt amacı olan ortaokul öğrencilerinin okuma alışkanlıklarında anne ve babalarının eğitim ve ekonomik durumlarının rolü hakkındaki görüşleri toplanmıştır. Bu görüşlere ilişkin alt temalar, kodlamalar ve frekans değerleri aşağıda Tablo 2'de sunulmuştur.

Tablo 2. Okuma alışkanlığında ebeveynin eğitim ve ekonomik düzeyinin rolü ana temasına ait alt temalar ve kodlar

\begin{tabular}{|c|c|c|c|}
\hline Alt Temalar & \multicolumn{2}{|r|}{ Kodlar } & Frekans \\
\hline $\begin{array}{l}\text { Ebeveynin eğitim } \\
\text { durumunun rolü }\end{array}$ & \multicolumn{2}{|c|}{$\begin{array}{l}\text { Çok etkili (TÖ.1, TÖ.13, TÖ.11), ebeveynden öğrenme (TÖ.1), model } \\
\text { (TÖ.1, TÖ.3, TÖ.6, TÖ.4,TÖ.19), okuma alışkanlığına sahip ebeveyn } \\
\text { (TÖ.2, TÖ.16), yaklaşım tarzı (TÖ.3, TÖ.16), destekleme (TÖ.3), } \\
\text { doğrudan ilişki (TÖ.3), kilit rol oynama (TÖ.4), yönlendirme (TÖ.5, } \\
\text { TÖ.12), önemi büyük (TÖ.5), tutum (TÖ.5), kontrol (TÖ.5), otoriter } \\
\text { (TÖ.5), akıl yürütücü (TÖ.5), ödüllendirici (TÖ.5), telkin (TÖ.6), eğitimli } \\
\text { ebeveyn (TÖ.6, TÖ.8, TÖ.12, TÖ.18), oldukça fazla (TÖ.7), yadsınamaz }\end{array}$} & $* 49$ \\
\hline \multicolumn{2}{|c|}{$\begin{array}{r}\text { Adres } \\
\text { RumeliDE Dil ve Edebiyat Arasttrmaları Dergisi } \\
\text { Osmanağa Mahallesi, Mürver Ciç̌ği Sokak, No:14/8 } \\
\text { Kadı̈öy - İTANBUL / TÜRKIYY } 34714 \\
\text { e-posta: editor@rumelide.com } \\
\text { tel: +90 } 5057958124,+90216773 \text { o } 616\end{array}$} & $\begin{array}{l}\text { Address } \\
\text { RumeliDE Journal of Language and Literature Studie } \\
\text { Osmanağa Mahallesi, Mürver Ciceği Sokak, No:14/8 } \\
\text { Kadıköy - ISTANBUL / TURKEY } 34714 \\
\text { e-mail: editor@rumelide.com, } \\
\text { phone: +90 505 7958124, +90 } 216773 \text { o } 616\end{array}$ & \\
\hline
\end{tabular}


Ebeveynin ekonomik durumunun rolü etkili

Ebeveynin ekonomik durumunun rolü etkili değil. sonuçlar (TÖ.8), okuma alışkanlığının başlangıcı aile (TÖ.9), anne-baba etkisi (TÖ.9), așlamak (TÖ.11), birlikte okuma (TÖ.11), bilinçli ebeveyn (TÖ.11, TÖ.12, TÖ.16), doğru orantılı yükselme (TÖ.13), elbette (TÖ.14, TÖ.17), tek kıstas değil (TÖ.14), bilinçlendirme (TÖ.15), kesinlikle farklı (TÖ.16), sorgulayan ebeveyn (TÖ.16), katkı (TÖ.17, TÖ.18), teşvik (TÖ.17), şekillendirme (TÖ.19).

Hayata bakış (TÖ.1), öncelikler (TÖ.1), hayat mücadelesi (TÖ.1), etkili (TÖ.2, TÖ. 3, TÖ.6, TÖ.7, TÖ.15), bilinç (TÖ.2), lüks tüketim (TÖ.2), para harcama (TÖ.2), açlık (TÖ.2), kütüphaneler (TÖ.2, TÖ.3, TÖ.6, TÖ.11, TÖ.15, TÖ. 16), maddi imkânsızlık (TÖ.3, TÖ.13, TÖ.18), destekleme (TÖ.3), kitaba ulaşma (TÖ.4, TÖ.6, TÖ.7 TÖ.13), engel (TÖ.4, TÖ.6), önemli paralellik var (TÖ.8), geçim sıkıntısı (TÖ.8), okumaya yatkın olma (TÖ.9), önemli (TÖ.11), külfet (TÖ.11), kitap temin etmek (TÖ.11), ekonomik sıkıntı (TÖ.12, TÖ.17), güçleştirme (TÖ.12), olumsuz etki ( TÖ.17), doğru orantılı (TÖ.13), zarar vermek (TÖ.15), az etki (TÖ.16, TÖ.19), ekonomik durum (TÖ.18), istediğini alma şansına sahip olma (TÖ.18), ayda bir kitap (TÖ.18).

Etkili değil (TÖ.5, TÖ.10, TÖ.14), kütüphane (TÖ.5, TÖ.19), internet (TÖ.5), okul kitaplıkları (TÖ.5), arkadaş grubu (TÖ.5), kitaba ulaşmak kolay (TÖ.5, TÖ.10), alternatifler (TÖ.10).

*Katılımcı öğretmenler öğrencilerin okuma alışkanlığında ebeveynin eğitim ve ekonomik düzeyinin rolüne ilişkin birden fazla görüş ifade ettiklerinden elde edilen toplam frekans sayısı katılımcı öğretmen sayısından fazladır.

Tablo 2'ye bakıldığında “Okuma Alışkanlığında Ebeveynin Eğitim ve Ekonomik Düzeyinin Rolü” ana teması altında üç alt tema verilmektedir. Bu üç alt temadan biri olan "Ebeveynin eğitim durumunun rolü” ne ilişkin bulguların kodlarında, araştırmaya katılan tüm Türkçe öğretmenleri ortaokul öğrencilerinin okuma alışkanlığı kazanmasında ebeveynlerinin eğitim durumunun yüksek olmasının öğrencilere okuma alışkanlığını kazanmasında doğrudan ilişkili olduğunu (f:49) ifade ettikleri yer almaktadır. Genel olarak katılımcı Türkçe öğretmenlerine göre eğitim düzeyi yüksek ebeveyn öğrenciye rol model olmakta, onu okumaya teşvik ederek yönlendirmekte ve onun alışkanlığını kazanmasında etkili olmaktadır. Bu ifadelerden bazıları aşağıda sunulmuştur:

“Oldukça fazla. Üniversite mezunu veli profilim yüzde on civarmda. Genel olarak velilerimin yüzde altmışı lise mezunu. Yüzde yirmi ilkokul mezunu; yüzde on ise hiç okuma yazma bilmiyor. Bu velilerimin arasında üniversite mezunu öğretmen ve çeşitli kurum personeli çocuklarmın okuma alsşkanlı̆̆ en yüksek düzeyde. Bu veliler evde düzenli okuma saatleri yapıyorlar. Bu nedenle bu velilerin çocukları okuma alışkanlı̆̆na sahip oluyor. Genel olarak veliler çocuklarını okumasın istiyor ama velilerin eğitim düzeyi düştükçe çocuklarm okuma ahşkanlı̆ına sahip olma oranı düşüyor. Ancak istisnai durum dahi olsa düşük eğitim seviyesine sahip velinin çocuğunda okuma alışkanlı̆̆ oluşabiliyor. Bunda aileden ziyade çevresel faktörler etkili oluyor.” (TÖ.7)

“Öğrencilerin okuma alışkanlı̆̆ kazanmasında ebeveynlerinin eğitim durumunun önemi büyüktür. $\mathrm{Bu}$ durum çocuğun öğrenmeye karşı tutumunu belirler. Ĕ̆itim durumu yüksek ebeveynlerin çocuklarını özel bir kişilik yapısına sahiptirler. Kendi kararların verebilmeleri ve bir yetişkin gibi davranmalar yönünde ebeveynleri tarafindan yönlendirilirler. Ĕ̆itim düzeyi yüksek ebeveynler diğerlerine göre daha fazla kontrol edicidir. Bu kontrol gücünü otoriter bir şekilde kullanurken akıl yürütücü ve yerine göre ödüllendirici bir özelliğe sahiptirler.” (TÖ.5)

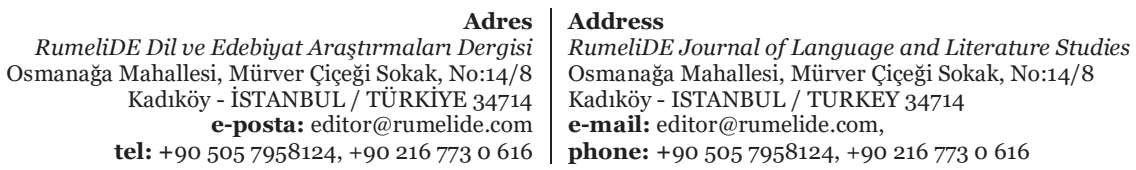


"Elbette anne ve babaların eğitim düzeyleri çocuklarm okuma alş̧kanhğı edinmelerinde etkili ancak tek kıstas bu değil. Anne ve babaları ilkokul mezunu olup okumaya ve gelişmeye çok yatkn öğrenciler de var. Ayn zamanda bu durumun tam tersi de mevcut." (TÖ.14)

"Burada tabii ki kilit role sahip olan anne ve babadır. Anne ve babanın eğitim durumları tabii ki önemli ancak yetersiz kahr, diye düşünüyorum. Asll önemli olan evde kitap okuyarak öğrenciye model olmalarıdır. Ağaca çıkan keçinin dala bakan oğlağı misali... Kendimden bir örnek vermek istiyorum: Çocuğuma iki yaşından beri kitap okurum. Her akşam mutlaka okurdum. Şu an üçüncü sinıfa gidiyor. Akşam kitap okumadan uyumaz.” (TÖ.4)

"Kesinlikle etkiliyor. Ĕ̆itim seviyesi yüksek olan bir velinin çocuğuna yaklaşımı, bilinci mutlaka diğer velilerden farkh oluyor. Çocuğuyla beraber okuyan ve sorgulayan veli, bir öğretmen olarak arzu ettiğimiz veli profilidir. Nitekim eğitim seviyesi yüksek olan veliden bunları nispeten de olsa görebiliyoruz."(TÖ.16)

"Bilinçli ve eğitimli anne ve babalar evde günün belli saatini okuma saati olarak düzenliyorlar. Velilerin eğitim düzeyi düştükçe çocuklarmı okumaya yönlendirmeleri azalıyor.” (TÖ. 12)

Yine Tablo 2'ye bakıldığında ebeveynin ekonomik durumunun öğrencilerin okuma alışkanlığındaki rolüne ilişkin görüşlerinden ortaya konulan kodlamalarla oluşturulan iki alt tema görülmektedir. Bu iki alt temaya ait kodlar incelendiğinde, öğrencilerin okuma alışkanlığında ebeveynin ekonomik durumunun rolünün etkili olduğuna yönelik oluşturulan alt temaya ait katılımcı görüşlerinin fazlasıyla ağır bastığı (f:45) söylenebilir. Ebeveynin ekonomik durumunun rolünün etkisiz olduğuna yönelik alt temaya ait katılımcı görüşlerinin ise önceki alt temaya kıyasla düşük (f:11) olduğu ifade edilebilir. Bu bağlamda araştırmaya katılan Türkçe öğretmenleri çoğunlukla ebeveynlerin geçim sıkıntısı, maddi imkânsızlık içinde olmasının öğrencinin okuma materyallerine ulaşmasını güçleştirdiğini ve dolayısıyla okuma alışkanlığına sahip olmasını olumsuz etkilediğini belirtmişlerdir. Ancak bu noktada söz konusu maddi zorlukların öğrencilerin gerek okul gerekse il halk kütüphanelerine yönlendirilmesi veya çeşitli desteklemeler ve çözüm yollarıyla kitap temin etmelerinin sağlanmasıyla aşılabileceği yine katılımcı öğretmenler tarafından ifade edilmiştir. Diğer taraftan öğrencilerin okuma alışkanlığına sahip olmalarında ebeveynlerinin ekonomik durumunun etkili olmadığı görüşünde olan bazı katılımcılar ise, günümüzde okuma materyallerine ulaşmanın kolaylı̆̆ına ve çeşitli alternatifleri olduğuna değinmişleridir. Katılımcıların ifadelerden dikkat çekici bazı doğrudan alıntılar aşağıda verilmektedir:

"Ailelerin sosyo-ekonomik durumu hayatı bütünüyle etkiler. Öğrencinin tüm yaşamı bundan etkilendiği gibi okuma alş̧kanh ğı da elbette bundan nasibini alır. Fakat okuyan ve okuma isteği olup da maddi imkânsızlklardan kitap temininde sorun yaşayan öğrencilerimize kütüphanemizden veya kendimize ait kitaplardan destek sunmaktayız. Bunu bir sorun olarak görmek ve çözüm arayışına girmemenin soruna kayıtsız kalmak dışında bir anlamı olmadı̆̆ı kanısındayım. Bizleri arayıp almaların istediğimiz hikâye kitapların maddi imkânsızlıtan alamadığını belirten velilerimiz sürekli vardır. Bu durumlarda okul idaresi, kendimiz ve kurtasiyelerin katkılarıyla öğrencilerimizi kitaplarla buluşturmaktayız." (TÖ.3)

"Ekonomi her şeyin temelidir. Bu nedenle ekonomik şartlar iyi düzeyde olan ailelerin-özellikle eğitim seviyesi yüksek velilerin-kitaba özel bir bütçe ayırdığı, dolayısıyla çocuklarnn okuma materyallerine ulaşmakta sıkıntı çekmediğini görmekteyim. Aksi durumda olanlar ancak imkânları ölçüsünde kitaba

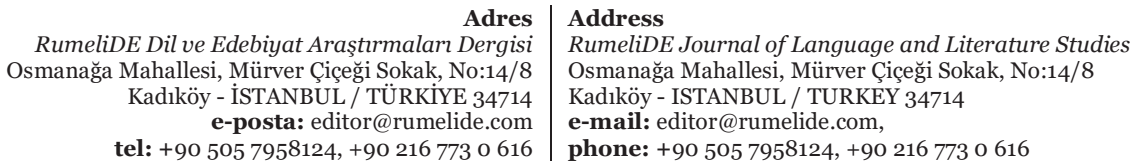


erişebildiğinden bu durum çocuğun okuma alışkanlı̆̆ın edinmesinde veyahut edinememesinde etkili olmaktadir."(TÖ.6)

"Ailenin maddi durumunun iyi olmaması öğrencinin kitaba ulaşmaması anlamına geliyor. Kitaba ulaşmayan bir öğrencinin bu alş̧kanlı̆̆ kazanmasını beklemek abes olur.” (TÖ.4)

"Ekonomik durum biraz etkilidir. Ama çok da değildir, dìye düşünüyorum. Çünkü çocuk okumak isterse okullarda, kütüphanelerde bile çok sayıda kitap var. Dağdaki çobanlarmız bile derece yapabiliyorsa ekonomik faktör çok da büyük engel değildir diye düşünüyorum.” (TÖ.19)

“Öğrencilerin okuma alıskanlğına ailelerinin ekonomik durumunun etki ettiğini düş̋ünmüyorum. Çağımızda kitaplara ulaşmak her sosyo-ekonomik durum için gayet basittir. Kütüphanelerden, internetten, okuldaki kitaplıklardan faydalanabilirler. Ayrıca arkadaş gruplarıyla da kitap alşverişinde bulunabilirler." (TÖ.5)

\section{Tema 3: Okuma alışkanlığına engel unsurlar}

"Okuma Alışkanlığına Engel Unsurlar" ana teması katılımcı öğretmenlerin, öğrencilerinin okuma alışkanlığına sahip olmalarının önünde engel olarak gördükleri unsurların kodlanmasıyla oluşturulmuştur. Bu ana temaya bağlı olarak kodlanan ifadeler yedi alt tema altında toplanmış ve bu veriler Tablo 3 'te sunulmuştur.

Tablo 3. Okuma alışkanlığına engel unsurlar ana temasına ait alt temalar ve kodlar

\begin{tabular}{|c|c|c|}
\hline Alt Temalar & Kodlar & Frekans \\
\hline $\begin{array}{l}\text { Televizyon izleme ve Teknolojik } \\
\text { iletişim araçlarını olumsuz etkisi }\end{array}$ & $\begin{array}{l}\text { Teknolojik araçlar (TÖ.5, TÖ.6, TÖ.7, TÖ.10), yanlış } \\
\text { teknoloji algısı (TÖ.8), olumsuz teknoloji (TÖ.9), teknoloji } \\
\text { bağımlılığı (TÖ.13), aşırı kullanım (TÖ.15), gereksiz } \\
\text { kullanım (TÖ.15), iletisim araçları (TÖ.17), tablet (TÖ.1, } \\
\text { TÖ.8, TÖ.15,TÖ.16, TÖ.18), telefon (TÖ.1, TÖ.19), sosyal } \\
\text { medya (TÖ.1, TÖ.2), bilgisayar oyunları (TÖ.2, TÖ.3, } \\
\text { TÖ.12, TÖ.15, TÖ.16,TÖ.18), bilinçsiz internet kullanma } \\
\text { (TÖ.3, TÖ.8), sanal âlem (TÖ.17), televizyon izleme (TÖ.1, } \\
\text { TÖ.2, TÖ.7, TÖ.8, TÖ.12, TÖ.15, TÖ.16) }\end{array}$ & ${ }^{*} 35$ \\
\hline Ailesel unsurlar & $\begin{array}{l}\text { Ailenin duyarsızlı̆̆ı (TÖ.2), aile (TÖ.3), eğitimsiz ebeveyn } \\
\text { (TÖ.4, TÖ.9), kayıtsız aile (TÖ.5), aile ortamı (TÖ.7), } \\
\text { bilinçsiz ebeveyn (TÖ.7, TÖ.13), sorumsuz ebeveyn (TÖ.8), } \\
\text { rol model eksikliği (TÖ.10), yetersiz ilgi (TÖ.18), ailenin } \\
\text { tutumu (TÖ.19), }\end{array}$ & 12 \\
\hline Öğretmen & $\begin{array}{l}\text { Öğretmen (TÖ.3, TÖ.6), ev ödevi verme (TÖ.6), okumanın } \\
\text { önemini kavratmama (TÖ.13). }\end{array}$ & 4 \\
\hline Bireysel unsurlar & $\begin{array}{l}\text { İhtiyaç görmeme (TÖ.1), maddi karşıllk görmeme (TÖ.2), } \\
\text { zevkine uygunluk (TÖ.2), isteksizlik (TÖ.5), } \\
\text { yönlendirilmeme (TÖ.10), zor görme (TÖ.11, TÖ.19), ilgi } \\
\text { duymama (TÖ.12), baskı hissetme (TÖ.12), olumsuz yargı } \\
\text { (TÖ.12), seviyeye uygunluk (TÖ.12), zaman yönetimi } \\
\text { (TÖ.14), bağımsız planlama (TÖ.14), gönüllerince hareket } \\
\text { etme isteği (TÖ.14), bağımsız zaman (TÖ.17), önem } \\
\text { vermeme (TÖ.18), gereksiz görme (TÖ.18), kitabı sevmeme } \\
\text { (TÖ. 18). }\end{array}$ & 18 \\
\hline Çevresel unsurlar & $\begin{array}{l}\text { Çevresel etkenler (TÖ.4), yayım azlığı (TÖ.6), eğitimsiz } \\
\text { toplum (TÖ.9), düşük okuma (TÖ.9), ilgi çeken uyarıcılar } \\
\text { (TÖ16) }\end{array}$ & 5 \\
\hline
\end{tabular}

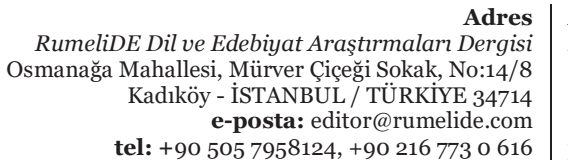

Adres
RumeliDE Dil ve Edebiyat Araştırmaları Dergisi
Osmanağa Mahallesi, Mürver Çiçeği Sokak, No:14/8
Kadıköy - İSTANBUL / TÜRKIYY 34714
e-posta: editor@rumelide.com
tel: +90 505 7958124, +90 216 7730616

Address

RumeliDE Journal of Language and Literature Studies

Osmanağa Mahallesi, Mürver Çiçeği Sokak, No:14/8

Kadıköy - ISTANBUL / TURKEY 34714

e-mail: editor@rumelide.com

phone: +90 $5057958124,+902167730616$ 


\begin{tabular}{|l|l|c|}
\hline Sinavlar & Testler (TÖ.6), sinavlar (TÖ.11), soru çözme (TÖ.11), & 3 \\
\hline Okul unsuru & $\begin{array}{l}\text { Erken dönem (TÖ. 3), ilkokul dönemi (TÖ.11), okul } \\
\text { etkinliklerinin azlığı (TÖ.13). }\end{array}$ & 3 \\
\hline
\end{tabular}

*Katılımcı öğretmenler öğrencilerin okuma alışkanlığına engel unsurlara ilişkin birden fazla görüş ifade ettiklerinden elde edilen toplam frekans sayısı katılımcı öğretmen sayısından fazladır.

Tablo 3 incelendiğinde, katılımcı Türkçe öğretmenlerinin ortaokul öğrencilerinin okuma alışkanlığına engel olan unsur olarak en fazla televizyon izleme ve teknolojik iletişim araçları (f:35) vurguladıkları, ardından ise sırasıyla bireysel unsurları (f:18), ailesel unsurları (f:12) ifade ettikleri görülmüştür. "Televizyon izleme ve teknolojik iletişim araçlarının olumsuz etkisi” alt teması altında kodlanan bu engel unsurlardan televizyon izleme (f:7), bilgisayar oyunları (f:6) ve tabletin (f:5) öne çıkan kodlardan olduğu söylenebilir. Katılımcı Türkçe öğretmenleri tarafından "Ailesel unsurlar" alt teması altında ifade edilen okuma alışkanlığına engel unsurlarda ebeveynlerin duyarsızlı̆̆ (TÖ.2), eğitimsizliği (TÖ.4, TÖ.9), kayıtsızlı̆̆ (TÖ.5), bilinçsizliği (TÖ.7, TÖ.13), sorumsuzluğu (TÖ.8), yetersiz ilgisi (TÖ.18), rol model eksikliği (TÖ.10) dikkat çekici bulgulardır. "Bireysel unsurlar" alt teması altında katılımcı görüşlerine göre öğrencilerin okuma alışkanlığı kazanamamasına neden olan kendilerinden kaynaklı engellere yer verilmiştir. Bu engellerden bazıları; öğrencilerin okumayı bir "ihtiyaç” (TÖ.1) olarak görmemeleri, okumaya yönelik gelecekte bir "maddi karşılık görmeme” leri (TÖ.2), "isteksizlik" leri (TÖ.5), okumayı "zor” (TÖ.11, TÖ.19) olarak görmeleri , "ilgi duymama”, "olumsuz yargı” ya (TÖ.12) sahip olmaları, "gönüllerince hareket etme” (TÖ.14) isteği, okumaya "önem vermeme”, okumayı "gereksiz görme”, "kitabı sevmeme" leri (TÖ. 18) ve zaman yönetimi, bağımsız planlama (TÖ.14) yapamamaları çarpıcı bulgulardandır. Bu bulguların elde edildiği Türkçe öğretmenlerinin görüşlerinden bazılarına aşağıda yer verilmiştir:

“En büyük engel ailenin tutumu bence. Çocuğa neyi öğretiyorsak onu yapar. Daha bir yaşında çocuklarımızın eline telefon verirsek onun yerine kitaplar zor geçer.” (TÖ.19)

“Teknolojik gelişmeler, ailelerin bu duruma kayıtsız kalması, öğrencilerdeki başarmaya karşı isteksizlik gibi durumlar okuma alışkanlı̆̆na engel unsurlarm başında gelmektedir.” (TÖ.5)

"Televizyon, tablet, bilgisayar aşır derecede ve gereksiz kullanılmaktadır. Bunlar okula, eğitime, okumaya pek katkı sağlamıyor.” (TÖ.15)

“Ortaokul öğrencilerinde okuma alsşkanhı̆ına engel olan en önemli faktörler; teknolojik gelişmeleri yanlsş anlama ve buna bağh olarak interneti televizyon, tabletin çocukların tüm zamanın işgal etmesidir. Sorumsuz ebeveynler de bu durumu daha da tetiklemektedir.” (TÖ.8)

“Sadece okuma ahşkanlığı değil, bütün alışkanlıklar zor edinilir ve zor terk edilir. İlk soruda da söylediğim gibi, ilkokuldan okuma alışkanlı̆̆ ile gelen öğrencide bu alışkanlı̆ı devam ettirmek kolayken, öğrenmeden gelene kazandırmak zor olabiliyor. En büyük engellerden biri, öğrencinin sinavlara, denemelere hazırlanmak adına soru çözmenin kitap okumaktan daha önemli olduğu yanılgısına düşmesi. Maalesef bazı velilerin de aynı fikirde olması.” (TÖ.11).

\section{Tema 4: Okuma alıșkanlığını kazanmada etkili unsurlar}

Araştırmaya katılan Türkçe öğretmenlerinin, öğrencilerin okuma alışkanlığı kazanmasında etkili olan unsurların neler olduğuna yönelik görüşleri kodlanarak “Okuma Alışkanlığını Kazanmada Etkili

RumeliDE Journal of Language and Literature Studies

Osmanağa Mahallesi, Mürver Çiçeği Sokak, No:14/8

Kadıköy - ISTANBUL / TURKEY 34714

e-mail: editor@rumelide.com,

phone: +90 5057958124, +90 2167730616
} 
336 / RumeliDE Journal of Language and Literature Studies 2022.26 (February)

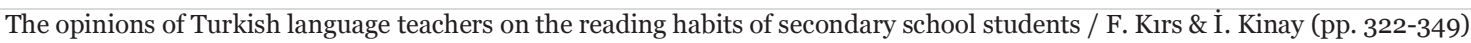

Unsurlar" ana teması oluşturulmuştur. Bu ana tema çatısı altında ise sekiz alt tema sıralanmıştır. Bu veriler aşağıda Tablo 4’te sunulmuştur.

Tablo 4- Okuma alışkanlığını kazanmada etkili unsurlar ana temasına ait alt temalar ve kodlar

\begin{tabular}{|c|c|c|}
\hline Alt Tema & Kodlar & Frekans \\
\hline Rol -model & $\begin{array}{l}\text { Aile (TÖ.1,TÖ.2, TÖ.3, T.Ö.5, TÖ.6, TÖ.7, TÖ.11, TÖ.13, TÖ.15, } \\
\text { TÖ.16, TÖ.18), ögretmenler (TÖ.1, TÖ.2, TÖ.3, TÖ.5, TÖ.6, } \\
\text { TÖ.7, TÖ.12, TÖ.15, TÖ.16, TÖ.17, TÖ.18), arkadaslar (TÖ.1, } \\
\text { TÖ.2, TÖ.3, TÖ.6), sosyal çevre (TÖ.6), taklit (TÖ.11), rol- } \\
\text { model (TÖ..3, TÖ.7, TÖ.15, TÖ.18), okuyan kardeşler (TÖ.15), } \\
\text { sürükleme (TÖ.15), ilgili anne-baba (TÖ.17), eğitimli anne- } \\
\text { baba (TÖ.4, TÖ.17), idareci (TÖ.18), hizmetli (TÖ.18), doğru } \\
\text { anne-baba tutumu(TÖ.19), birlikte okuma (TÖ.19). }\end{array}$ & $* 41$ \\
\hline Farkındalık Oluşturma & $\begin{array}{l}\text { Kitapla tanıştırma (TÖ.2), ilgi (TÖ.5), kitap seçimi yaptırma } \\
\text { (TÖ.5), telkin (TÖ.6, TÖ.17), teşvik (TÖ.6, TÖ.17), destekleme } \\
\text { (TÖ.6, TÖ.18), erken yaşlar (TÖ.7), 5.sınıfta başlama (TÖ.10), } \\
\text { yazar tanıtımı (TÖ.10), kitap kulüpleri (TÖ. 10), münazara (TÖ. } \\
\text { 10) kitap inceleme (TÖ.10), fuar ziyareti (TÖ.12), kitap tanıtım } \\
\text { günleri (TÖ.12), okumanın önemini kavratma (TÖ.13), } \\
\text { kademeli yaklaştırma (TÖ.14), ödül verme (TÖ.17), evde } \\
\text { okuma saatleri yapma (TÖ.17, TÖ.18), }\end{array}$ & $* 22$ \\
\hline Bireysel çaba & $\begin{array}{l}\text { Başarı arzusu (TÖ.5), kitap sevgisi (TÖ.8), haz duyma (TÖ.8), } \\
\text { plan (TÖ.11) }\end{array}$ & 4 \\
\hline Okul etkinlikleri & $\begin{array}{l}\text { Okuma saatleri (TÖ.2, TÖ.4, TÖ.13, TÖ.17, TÖ.18), rehberlik } \\
\text { (TÖ.3, TÖ.10), okul (TÖ.16), }\end{array}$ & 8 \\
\hline Kütüphane & $\begin{array}{l}\text { Okuma merkezi (TÖ.2), kütüphane ziyaretleri (TÖ.4, TÖ.12), } \\
\text { okul kütüphaneleri (TÖ.13), sinıf kütüphaneleri (TÖ.13), }\end{array}$ & 5 \\
\hline Kitaplar & İlgi çekici kitaplar (TÖ.6, TÖ.14), & 2 \\
\hline Teknoloji Kullanımı & $\begin{array}{l}\text { Doğru teknoloji kullanımı (TÖ.9), televizyon sınırlaması } \\
\text { (TÖ.4), televizyon/medya tanıtımı (TÖ.12) }\end{array}$ & 3 \\
\hline Eğitim Sistemi & Sinav odaklı eğitim (TÖ.9), & 1 \\
\hline
\end{tabular}

*Katılımcı öğretmenler öğrencilerin okuma alışkanlığı kazanmasında etkili unsurlara ilişkin birden fazla görüş ifade ettiklerinden elde edilen toplam frekans sayısı katılımcı öğretmen sayısından fazladır.

Tablo 4’te, araştırmaya katılımcı Türkçe öğretmenlerinin görüşlerine göre, öğrencilerin okuma alışkanlı̆̆ı kazanmasında etkili olan unsurlar, büyük çoğunlukla öğrenciye örneklik teşkil ettiklerini düşündükleri ve araştırmada "Rol-model" alt teması (f:41) altında verilen kodlardır. Bu kodlardan en fazla kullanılanlar sırasıyla "aile" (f:11), öğretmenler (f:11) ve arkadaşlar (f:4) olmuştur. Bu alt temanın ardından kullanılan ifadelerin frekansı baz alındığında ikinci olarak "Farkındalık oluşturma" alt teması altında kodlanan unsurlar (f:22) gelmektedir. Bu temada en çok kullanılan kod ise "evde okuma saatleri” (f:2) olmuştur. Tablo 4’te katılımcıların görüşlerine göre, öğrencilerin okuma alışkanlı̆̆ kazanmasında etkili olan unsurlardan ikinci olarak en çok kullandıkların ifade kodlamaların yer aldığı bir diğer alt tema ise "Okul etkinlikleri" dir (f:8). Bu alt tema altında en çok tekrarlanan kod ifadeler; okullarda yapılan "okuma saatleri" (f:5) ve "rehberlik" (f:2) olmuştur. Bu kodlamaların yer aldığı katılımcıların görüşlerinden bazı alıntılara aşağıda yer verilmiştir:

"Ailede anne, baba, kardeş rol model olmakta. Okuyan biri varsa ailede abla abi gibi, onlarm da etkisi oluyor. Öğretmen gerçekten okumanin sırrına vakıf olmuşsa sürükler peşinden.” (TÖ.15)

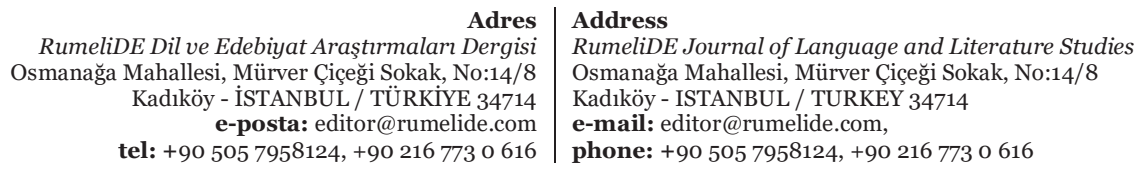


"En önemli faktör ailedir. Evde isteyerek yapılmayan okuma nasıl işe yaramayacak ise, öğretmen istedi diye yapılan okuma da çok faydah olmayacakttr." (TÖ.11)

“Öncelikle ebeveynler, öğretmenler ve arkadaşların etkili olduğuna inanıyorum.” (TÖ.1)

"Çocuğun okuma alşskanhğında en önemli rol öğretmene düşmektedir. Öğretmenin sinıfta kitap okuması, okuduğu kitaplardan söz etmesi en önemli faktördür. Televizyon ve medya yayınlarnnda sık sık kitap tanıtımlarının yapılması önemli faktörlerden biridir. Fuarlar, kitap tanıtım günleri ve kütüphane gezileri öğrencilerin okuma alıskanlı̆ında önemli rol oynamaktadır.”(TÖ. 12)

\section{Tema 5: Okuma alışkanlığının akademik başarıya etkisi}

Katılımcı Türkçe öğretmenlerinin, ortaokul öğrencilerinin okuma alışkanlıkları ile akademik başarıları arasında bir ilişki olup olmadığıyla ilgili görüşlerinin kodlanmasıyla oluşturulan "Okuma Alışkanlığı ile Akademik Başarı İlişkisi” ana temasına ve bu ana tema altında yer alan dört alt temaya ait kod ve frekansları aşağıda Tablo 5’te verilmiştir.

Tablo 5. Okuma alışkanlığı ile akademik başarı ilişkisi ana temasına ait alt temalar ve kodlar

\begin{tabular}{|c|c|c|}
\hline Alt Tema & Kodlar & Frekans \\
\hline Akademik başarıyı arttırır & $\begin{array}{l}\text { Mühakkak/kesinlikle/evet (TÖ.1, TÖ.2, TÖ.3, TÖ.6, TÖ.9, } \\
\text { TÖ.10,TÖ.12, TÖ.17, TÖ.18, TÖ.19), ögrenmeyi öğrenme } \\
\text { (TÖ.2), paralel (TÖ.4), anahtar (TÖ.4), doğrudan ilişki } \\
\text { (TÖ.7), LGS başarısı (TÖ.7), doğrudan bağ (TÖ.13) } \\
\text { yüksek başarı (TÖ.5, TÖ.8, TÖ.10), fayda sağlama (TÖ.5), } \\
\text { tüm kademelerde (TÖ.11), eğitim sisteminde başarı } \\
\text { (TÖ.11), soruları rahat cevaplama (TÖ.12), zihni } \\
\text { geliştirme (TÖ.13), kelime hazinesini geliştirme (TÖ.3, } \\
\text { TÖ.13), sınav süresini kullanmayı arttırma (TÖ.13), diğer } \\
\text { derslerde başarı sağlama (TÖ.15, TÖ.17, TÖ.18), yeni nesil } \\
\text { sorularda başarılı olma (TÖ.15), iyi bir lise kazanma } \\
\text { (TÖ.16), sınav başarısı (TÖ.6, TÖ.17), sayısal derslerde } \\
\text { başarı (TÖ.17), ilişkili (TÖ.18), derse aktif katılım sağlama } \\
\text { (TÖ.18). }\end{array}$ & *37 \\
\hline Bilişsel becerileri geliştirir & $\begin{array}{l}\text { Anlama (TÖ.1, TÖ.2, TÖ.3, TÖ.4, TÖ.5, TÖ.6, TÖ.7, TÖ.8, } \\
\text { TÖ.9, TÖ.10, TÖ.11, TÖ.13, TÖ.18), muhakeme etme } \\
\text { (TÖ.1, TÖ.11), ilişkilendirme (TÖ.1), kavrama (TÖ.3, } \\
\text { TÖ.6), çlkarım yapma (TÖ.4), bilgi edinme (TÖ.10, TÖ.5), } \\
\text { inşa etme (TÖ.5), bilinç (TÖ.5), içselleştirme (TÖ.8), } \\
\text { çözümleme (TÖ.9), pratik (TÖ,12), kıvrak (TÖ.12), } \\
\text { yorumlama/ yorum gücü (TÖ.2, TÖ.3, TÖ.4, TÖ.7, TÖ.8, } \\
\text { TÖ.13, TÖ.18), algllama (TÖ.13), büyük farkındalık } \\
\text { oluşturma (TÖ.19) }\end{array}$ & * 36 \\
\hline Kişisel gelişime katkı sağlar & $\begin{array}{l}\text { Okuduğunu anlamada daha becerikli olma (TÖ.14), öz } \\
\text { güven (TÖ.18), ifade becerileri (TÖ.4, TÖ.18), sözlü ifade } \\
\text { becerisi (TÖ..2, TÖ.6, TÖ.7), iletişim (TÖ.5), yazılı ifade } \\
\text { becerisi (TÖ.6, TÖ.7) }\end{array}$ & 10 \\
\hline $\begin{array}{l}\text { Problem çözme becerisi } \\
\text { kazandırır }\end{array}$ & $\begin{array}{l}\text { Güçlükleri çözme (TÖ.12), sorun çözme (TÖ.2), etkili } \\
\text { çözme (TÖ.5) }\end{array}$ & 3 \\
\hline
\end{tabular}

*Katılımcı öğretmenler öğrencilerin okuma alışkanlığı ile akademik başarı ilişkisine yönelik birden fazla görüş ifade ettiklerinden elde edilen toplam frekans sayısı katılımcı öğretmen sayısından fazladır.

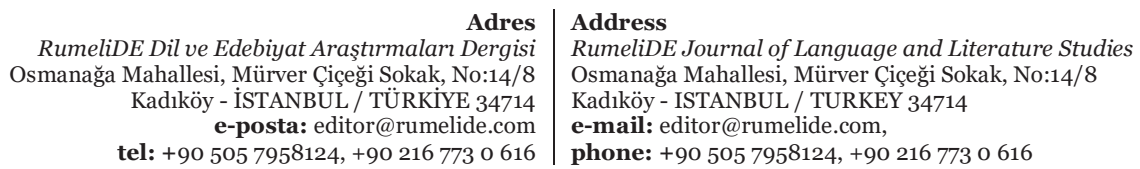


Yukarıda Tablo 5'te görüldüğü üzere, araştırmaya katılan Türkçe öğretmenlerinin tamamı öğrencilerinin okuma alışkanlıkları ile akademik başarıları arasında doğru orantılı bir ilişki olduğu görüşündedirler. Öğretmenlerin görüşlerinden yola çıkllarak bu ilişki dört alt temada kategorize edilmiştir. Bu alt temalardan frekans değerleri en yüksek olan ve öğretmenlerin çoğunluğunun mutabık olduğu görüşlerinin yer aldığı okuma alışkanlığı "Akademik başarıyı attırır" (f:38) ve "Bilişsel becerileri geliştirir" (f:37) alt temaları ile olmuştur. "Akademik başarıyı attırır" alt temasında öğretmenlerin yüksek oranda okuma alıskanlığının öğrencilerin tüm kademe ve derslerde başarısını arttırdığı yönündeki verileri "Muhakkak/ kesinlikle/ evet” (f:10), “doğrudan bağ”(f:1), doğrudan ilişki”(f:1), "paralel” (f:1), “tüm kademelerde”(f:1), “diğer derslerde başarı”(f:3), “yüksek başarı”(f:3) kodlarıyla özetlenebilir. Öğretmenlerin yüksek oranda ifade ettiği görüşlerinin yer aldığı bir diğer alt tema olan "Bilişsel becerileri geliştirir" temasında okuma alışkanlığının öğrencilerin "anlama” (f:13), "yorumlama/ yorum gücü” (f:7) becerilerini geliştirdiği bulgusuna ulaşılmıştır. Bu alt temayı takiben yine öğretmenlerin okuma alışkanlığının en çok öğrencilerin kişisel gelişimine katkı sağladığını belirttikleri sonucuna ulaşılmıştır. Bu ifade kodları (f:10) "Kişisel gelişime katkı sağlar" alt teması altında yer bulmuştur. Katılımcı Türkçe öğretmenlerinin bu temayı oluşturan görüşlerinden bazıları aşağıda doğrudan alıntı şeklinde verilmiştir:

"Evet, kesinlikle. Özellikle son yıllarda, tüm derslerde öğrencinin ne istenildiğini doğru anlaması cevabı vermede çok etkili. Yapılan sınavlarda artık salt bilginin sorulmadiğımı, okuduğunu anlama, ilişkilendirme, muhakeme kurma gibi becerilerin sorgulandiğın görmekteyiz. Bu da kitap okumanın önemini ortaya çlkarmaktadır. Büyüklerimiz 'Soruyu anlamak, cevabın yarısıdır.' derlerdi.” (TÖ.1)

"Yillardır liselere öğrenci hazırlayan bir öğretmen olarak şunun altını çizmek isterim: ' Kitap okuma alşskanliğın kazanmamış bir çocuk iyi bir liseyi kazanamaz.' Bu dediğim ifade gözlemlerim neticesinde ortaya çıkmıştır. Fen ve Anadolu liselerini (Proje okul kapsamındakiler) kazanan öğrencilerde bunu net olarak görmekteyiz.” (TÖ.16)

"Okuma alışkanlığı ve başarı arasında doğrudan bir bağ vardır. Okuma hem zihni geliştirip yorum gücünü arttrrı hem de öğrencinin kelime hazinesini geliştirerek algılamayı ve sinav süresini iyi kullanmasına katkı sağlar.” (TÖ.13)

"Kesinlikle. Öğrenmeyi öğrenen çocuk Türkçe dersinde ve diğer derslerde de anlama ve yorumlama gücüyle başarılı olmaktadır. Okuyup da başarılı olmayan öğrenciyi hiç görmedim. Ayrıca çok okuyan öğrenci kendini daha rahat ifade edebildiği için bu durum ona okul içi ve dışı sorun çözme becerisi kazandirıyor. Bu da akademik başarıyı sağlamaktadır.” (TÖ.2)

\section{Tema 6: Okuma alışkanlığını kazandırmaya yönelik öneriler}

Araştırmaya katılan Türkçe öğretmenlerinin, ortaokul öğrencilerine okuma alışkanlığını kazandırmaya yönelik önerilerinin neler olduğuyla ilgili görüssleri kodlanarak "Okuma Alışkanlığını Kazanmaya Yönelik Öneriler" ana teması altında bir araya getirilmiştir. Bu kapsamda katılımcı öğretmenlerin ortaokul öğrencilerine okuma alıskanlığı kazandırmaya yönelik önerilerine ait alt temalar, kodlar ve frekans değerleri Tablo 6'da sunulmuştur.

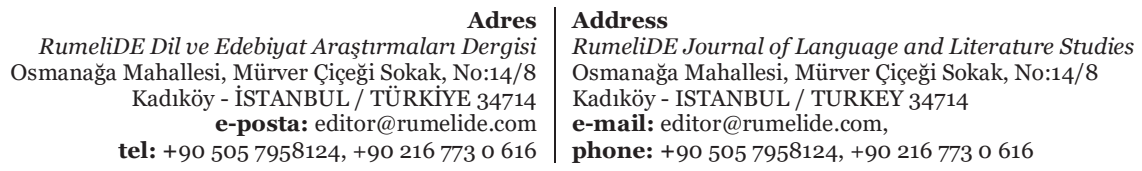


Tablo.6 Okuma Alışkanlı̆̆ını Kazandırmaya Yönelik Öneriler Ana Temasına Ait Alt Temalar ve Kodlar

\begin{tabular}{|c|c|c|}
\hline Alt Tema & Kodlar & Frekans \\
\hline Aileye yönelik öneriler & $\begin{array}{l}\text { Aile içi kitap okuma (TÖ.1), ebeveyn bilinçlendirme } \\
\text { çalışmaları/seminerleri (TÖ.2, TÖ.5, TÖ.6, TÖ.8, TÖ.9, } \\
\text { TÖ.10), kitaplı (TÖ.5), aile eğitimi (TÖ.7), ebeveynin } \\
\text { okuması (TÔ.11), sevgi dili kullanma (TÖ.14), evde } \\
\text { okumayı pekiştirme (TÖ.16), öğretmenle işbirliği (TÖ.16), } \\
\text { evde okuma saatleri (TÖ.18), }\end{array}$ & 14 \\
\hline Öğrencilere yönelik öneriler & $\begin{array}{l}\text { Hoşlanılan/zevke uygun kitaplar okuma (TÖ.1, TÖ.3, } \\
\text { TÖ.18), sorumluluk (TÖ.9), düzenli okuma (TÖ.11) }\end{array}$ & 5 \\
\hline $\begin{array}{l}\text { Okuma materyaline yönelik } \\
\text { öneriler }\end{array}$ & $\begin{array}{l}\text { Ücretsiz kitap dä̆ı̆tımı (TÖ.2, TÖ.6), kitap yayımının } \\
\text { arttırılması (TÖ. 6), e-okuma (TÖ.6), kitaplara erişim } \\
\text { kolaylı̆̆ı (TÖ.7), televizyonda kitap tanıtımı (TÖ.18), }\end{array}$ & 6 \\
\hline Okullara yönelik öneriler & $\begin{array}{l}\text { Okuma saatleri (TÖ.1, TÖ.5, TÖ.9, TÖ.11, TÖ.13, TÖ.17, } \\
\text { TÖ.18, TÖ.19), okuma atölyesi (TÖ.7), okul kütüphanesi } \\
\text { oluşturma (TÖ.7), kütüphaneyi işlevselleştirme (TÖ.7), } \\
\text { okul kütüphanesinin zenginleştirilmesi (TÖ.13), kitaba } \\
\text { ulassmayı kolaylaştırma (TÖ.14), yazar buluşmaları (TÖ.2, } \\
\text { TÖ.10,TÖ.15), tiyatro (TÖ.3, TÖ.15), sinema (TÖ.15), } \\
\text { sosyal faaliyetler düzenleme (TÖ.15), ödüllendirme } \\
\text { (TÖ.17, TÖ.18), belge verme (TÖ.17,) okuma kulüpleri } \\
\text { (TÖ.10), yarışmalar (TÖ.10, TÖ.13), }\end{array}$ & *26 \\
\hline Öğretmenlere yönelik öneriler & $\begin{array}{l}\text { Kitap kritiği (TÖ.1, TÖ.2), yaşa uygun kitaplar önerme } \\
\text { (TÖ..3), çeşitli yöntemleri deneme (TÖ.3), kitap okumaya } \\
\text { yönelik ev ödevi verme (TÖ.4), okumayı tavsiye etme } \\
\text { (TÖ.4), kitapläla tanıştırma (TÖ.8), kütüphane } \\
\text { ziyaretleri (TÖ.1O, TÖ.17), öğrenciye kitap seçme firsat } \\
\text { verme (TÖ.11, TÖ.14), hediye/ maddi teşvik (TÖ.4, TÖ.12, } \\
\text { TÖ.19), kitap sinavları (TÖ.12, TÖ.13), not ödülü (TÖ.12, } \\
\text { TÖ.19), rol-model olması (TÖ.13), sevgi dili kullanma } \\
\text { (TÖ.14), öğrenci isim/fotoğrafların panoya asılması } \\
\text { (TÖ.17), eğlenceli kitaplar okutma (TÖ.19) }\end{array}$ & $*_{22}$ \\
\hline $\begin{array}{l}\text { Kütüphanelere yönelik } \\
\text { öneriler }\end{array}$ & $\begin{array}{l}\text { Okuma merkezlerinin oluşturulması (TÖ.2), } \\
\text { kütüphaneleri zenginleştirme (TÖ.10), kütüphaneleri } \\
\text { işlevselleştirme (TÖ.10), }\end{array}$ & 3 \\
\hline
\end{tabular}

*Katılımcı öğretmenler öğrencilere okuma alışkanlığını kazandırmaya yönelik birden fazla öneri ifade ettiklerinden elde edilen toplam frekans sayısı katılımcı öğretmen sayısından fazladır.

Tablo 6 incelendiğinde, katılımcı Türkçe öğretmenlerinin, ortaokul öğrencilerinin okuma alışkanlığı kazanabilmesi için neler yapılabileceğine dair en fazla "Okullara yönelik öneriler"de (f:26) bulundukları görülmektedir. Bunun akabinde katılımcılar sırasıyla önce "Öğretmenlere yönelik öneriler”e (f:22) sonrasında ise "Aileye yönelik öneriler”e (f:14) daha çok değindikleri bulgusuna ulaşılmıştır. Okullara yönelik öneriler" alt temasında frekans sayılarıyla en dikkat çeken kod ifadeler okullarda yapılması tavsiye edilen "Okuma saatleri” (f: 8) ve öğrencilerle "Yazar buluşturmaları" (f:3) olmuştur. "Aileye yönelik öneriler” alt temasında ise frekans oranlarıyla göze çarpan kod ifadeler "Ebeveyn bilinçlendirme çalışmaları/seminerleri” (f:6) olmuştur. Katılımcı Türkçe öğretmenlerinin bu temayı oluşturan görüşlerinden bazıları aşağıda doğrudan alıntı şeklinde verilmiştir:

"Okuma saatleri yapılmalıdır. Kitap okuma yarışmalar düzenlenmelidir. Okul kütüphaneleri zenginleştirilmeli, aktif hale getirilmelidir. Sınav sorular kitap okumaya dönük sorulmahdır. Anne, baba, öğretmen ve idareciler kitap okuma konusunda iyi rol model olmalıdır.” (TÖ.13)

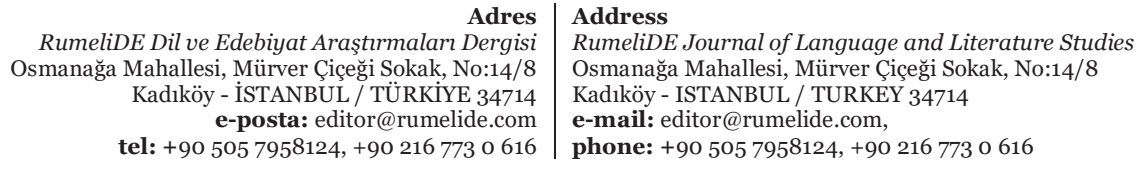


340 / RumeliDE Journal of Language and Literature Studies 2022.26 (February)

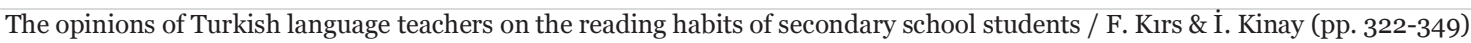

"Sosyal faaliyetler, tiyatro, sinema bile öğrencilerin okumaya yönlendirilmesinde etkili olabiliyor. Ayrıca öğrenciler yazarlarla buluşturulmal.”. (TÖ.15)

"Bence öğrencinin okuma alışkanlı̆̆ kazanması için başta anne, baba ve öğretmen olmak üzere herkesin üzerine düşeni yapması gerekir. Okullarda okuma saatleri düzenli yapılmah ve bu sadece Türkçe derslerinde yapılan bir etkinlik olarak görülmemeli. Diğer öğretmenlerin katılımı ve yardımıyla yapılmah. Ayrıca ailenin yani anne ve babanın, varsa diğer kardeşlerin evde bu etkinliğ in tamamlayıcı unsuru olduğu bilinmelidir.”(TÖ.9)

"Şu an okulumuzda yapıldığı gibi her gün bir saat okuma saatine ayrlabilir. Ebeveyn yardımı olmadan bunun başarllamayacağını farkma varlarak ebeveynleri mutlaka bu işe katmak gerekir. Öğrenciye kendine uygun kitap seçmesi sağlanmal. Çünkü öğrencinin kendisine hitap etmeyen kitapları okutturmak, ona okumayı sevdirmek yerine onun okumaktan nefret etmesine sebep olabilir. Ayrıca öğrencilere çok fazla okutmak yerine az da olsa düzenli okumayı öğretmek gerekir.” (TÖ.11)

"Öncelikle aile içerisinde kitap okumann bir kültür haline gelmesi gerekir. Daha sonra çocuğun hoşlandiğı kitaplarla başlaması önemli. Öğretmenlerin, özellikle de Türkçe öğretmenlerinin, okuma saatleri yapması, öğrencilerle kitap kritiğinin yapılması, kitap üzerinde bilgi alş̧verişinin yapılması öğrenciyi daha çok motive edecektir.” (TÖ.1).

\section{Sonuç ve tartışma}

Türkçe öğretmenlerinin görüşlerine dayalı olarak ortaokul öğrencilerinin okuma alışkanlığının incelendiği bu araştırmada elde edilen bulgularından yola çıkılarak ulaşılan sonuçlar tartışılmıştır. Araştırmada Türkçe öğretmenlerine belirlenen amaç ve alt amaçlar kapsamında yedi açlk uçlu araştırma sorusu sorulmuş ve öğretmenlerin verdikleri yanıtlar doğrultusunda altı ana tema oluşturulmuştur. $\mathrm{Bu}$ ana temalar alt temalarla ayrıntılandırılmaya ve kategorize edilmeye çalışılmıştır. Elde edilen bu tema ve alt temalara göre öğretmen görüşleriyle ilgili şu sonuçlara ulaşılmıştır.

Araştırmanın ilk teması olan "Öğrencilerin okuma alışkanlığı" altında çalışmaya katılan Türkçe öğretmenlerinin görüşleri incelendiğinde, ortaokul öğrencilerinin okuma alışkanlığı düzeyinin zayıf olduğu sonucuna ulaşılmaktadır. Alanda yapılan araştırmalara bakıldığında; Bayis (2010), tarafından yapılan 4. 5. 6. ve 7. sınıf öğrencilerinin kitap okuma ve kütüphane kullanım alışkanlıklarının incelendiği araştırmada, öğrencilerin kitap okuma alışkanlıklarının düşük düzeyde olduğu bulgusu mevcut araştırma sonucuyla paralellik taşımaktadır. Benzer şekilde ve Davarcı (2013)'nın, ilköğretim okullarındaki 8.sınıf öğrencilerinin kitap okuma alışkanlığını incelediği araştırmasında ve Güngör (2009)'ün, ilköğretim okullarındaki 5.sınıf öğrencilerinin kitap okuma alışkanlıklarını inceleyen araştırmasında, öğrencilerin fazla okuma alışkanlığı olmadı̆̆ı; Duran ve Sezgin (2012)'in ilköğretim 4 ve 5. sınıf öğrencilerinin okuma alışkanlıkları ve ilgilerini belirlemek amacıyla yaptıkları çalışmada, katılımcı öğrencilerinin büyük bir bölümünün okuma alışkanlığına sahip olmadıkları, orta ve alt düzey okuyucu oldukları; Acıyan (2008)'ın, ortaöğretim öğrencilerinin okuma alışkanlıkları ile akademik başarısı arasındaki ilişkiyi saptamaya çalıştığı araştırmada, öğrencilerin önemli bir bölümünün (\% 63.5) yeteri kadar kitap okumadığı; Taşkesenlioğlu (2013)'unun ortaöğretim kurumlarında öğrenim gören öğrencilerin okuma alışkanlığı üzerine yaptı̆̆ı inceleme sonucunda öğrencilerin önemli bir kısmının yeterli okuma alışkanlığına sahip olmadığı; Kaynar (2007)'ın ortaöğretim öğrencilerinin okuma alışkanlı̆̆ı ve iletişim becerilerini ölçmeyi amaçladığı çalışmada, çok az bir öğrenci kitlesinin okuma alışkanlığı olduğunu öğrencilerin büyük bir bölümünün kitap okuma alışkanlığı olmadığı tespit

\footnotetext{
Adres $\mid$ Address

RumeliDE Dil ve Edebiyat Araşttrmaları Dergisi Osmanağa Mahallesi, Mürver Çiçeği Sokak, No:14/8 Kadıköy - İSTANBUL / TÜRKIYE 34714 e-posta: editor@rumelide.com

RumeliDE Journal of Language and Literature Studies

Osmanağa Mahallesi, Mürver Çiçeği Sokak, No:14/8

Kadıköy - ISTANBUL / TURKEY 34714

e-mail: editor@rumelide.com,

tel: +90 5057958124, +902167730616 phone: +90 5057958124, +90 2167730616
} 
edilmiştir. Bunlara ilaven, Saracaloğlu, Karasakaloğlu ve Aslantürk (2010), Arı ve Demir (2013) ve Kara (2019) tarafından yapılan okuma alışkanlığına ilişkin farklı çalışmalarda Sınıf Öğretmenliği bölümü öğrencilerinin okuma alışkanlı̆̆ının yetersiz olduğu sonucuna ulaşılmıştır. Bu sonuçlara karşın; Aksoy ve Öztürk (2019), ilköğretim öğrencilerinin okuma alışkanlığı kazanma durumlarını, belirlemeye çalıştığı araştırmada öğrencilerin \%95,2'sinin okuma alışkanlı̆̆ının olduğunu, \%4,8’i ise olmadığı; İşcan, Arıkan ve Küçükaydın (2013)'ın, ortaokul öğrencilerinin kitap okuma alışkanlıklarını inceledikleri araştırmada öğrencilerin düzenli bir şekilde kitap okudukları; Bayat ve Çetinkaya (2018) 'nın ortaokul öğrencilerine yönelik yaptıkları çalışmada ulaştıkları katılımcıların \%60,1'inin okumaktan çok fazla haz aldığı, \%46'3'ünün hemen hemen her gün kitap okuduğu, \%57,1'inin yeteri kadar okuduğu; Deniz (2015), ortaokul öğrencilerinin \%53,2'sinin çok okuyan; Aksoy (2017)'un ortaokul öğrencilerinin okuma alışkanlığının ortanın üzerinde olduğu; Balcı (2009: 385) 8. sınıf öğrencilerinin \%70’inin orta, \%25'inin zayıf, \%15’inin de çok okuyan okur düzeyinde okuma alışkanlığına sahip oldukları bulgularıyla farklılaşmaktadır.

Araştırmanın ikinci teması olan "Okuma Alışkanlığında Ebeveynin Eğitim ve Ekonomik Düzeyinin Rolü”ne ilişkin bulgular değerlendirildiğinde, ortaokul öğrencilerinin okuma alışkanlığı kazanmasında ebeveynlerinin eğitim düzeylerinin ve ekonomik durumlarının etkili olduğu sonucuna ulaşılmaktadır. Türkçe öğretmenlerinin görüsslerine göre, ebeveynlerinin eğitim düzeylerinin yüksek olması öğrencilerin okuma alışkanlığını arttıran bir faktördür. Araştırmanın bu sonucu; Taşkesenlioğlu (2013) tarafından yapılan araştırmada elde edilen anne ve babanın eğitim seviyesi yüksekse öğrencide de paralel olarak okuma oranının yüksek olduğu yönündeki araştırma bulgusuyla; Güngör (2009) ve Bayis (2010), anne ve babaların eğitim düzeyleri yükseldikçe öğrencilerin kitap okuma alışkanlıklarının arttığına ilişkin bulguları ile örtüşmektedir. Aynı şekilde, Acıyan (2008)'ın, yaptığı araştırmada, ortaöğretim öğrencilerinin anne ve babalarının eğitim seviyesi arttıkça okudukları kitap sayısının arttı̆̆ı; Bekar (2005)'ı ilköğretim beşinci sınıf öğrencilerinin okuma alıskanlı̆̆ kazanmalarında ailelerin rolüne ilişkin yapmış olduğu araştırmada da üniversite mezunu olan annelerin $(X=48.61)$ ve lise mezunu annelerin ( $X=48.44)$, ortaokul mezunu annelere ( $X=43.9)$, ilkokul mezunu annelere ( $X=43.3)$ ve okuryazar olmayan annelere ( $\mathrm{X}=38.7)$ oranla çocuklarını okumaya yönlendirmelerinin daha fazla olduğu; üniversite ( $X=49.53)$ ve lise mezunu olan babaların $(X=45.59)$, ortaokul mezunu $(X=43.69)$ ve ilkokul mezunu babalara kıyasla $(\mathrm{X}=40.66)$ çocuklarını okumaya yönlendirmelerinin daha fazla olduğu belirlenmiştir. Suna (2006), tarafından ilköğretim öğrencilerinin okuma ilgi ve alışkanlıklarını etkileyen etmenlerin incelendiği çalışma sonuçlarına göre ise, ilköğretim öğrencilerinin anne ve babalarının öğrenim durumu yükseldikçe okuma ilgisi düzeyi de yükselmektedir. Bu araştırmalardan farklı olarak Davarcı (2013), anne ve babanın eğitim düzeyi yükseldikçe ilköğretim 8. sınıf öğrencilerinin boş zamanlarında daha az kitap okudukları sonucuna ulaşmıştır.

Araştırmanın ikinci temasına ait diğer bir sonuç olarak; katılımcı öğretmenlere göre, maddi sıkıntı yaşamayan ve ekonomik yönden iyi bir düzeyde olan ebeveynlerin çocukları diğerlerine kıyasla daha çok okuma alışkanlığına sahip olmaktadır. Bu sonucun, Keleş, Ö. (2006), Güngör (2009) ve Bayis (2010)'in, ailenin gelir düzeyi arttıkça öğrencilerin kitap okuma alışkanlık düzeyleri de arttığına ilişkin sonuçları ile örtüşmekte olduğu söylenebilir. Şahin (2009) tarafından ilköğretim 6. 7 ve 8. sinıf öğrencilerinin okuma alışkanlıklarını belirlemek amacıyla yapılan çalışmada farklı sosyo-ekonomik düzeye sahip öğrencilerin düzenli olarak kitap okuma alışkanlıklarında anlamlı farklılıkların olduğu tespit edilmiştir. Buna göre üst sosyo-ekonomik düzeydeki öğrencilerin \% 37,7'si ile orta sosyo-ekonomik düzeydekilerin \% 45,5’i her gün okumakta iken; alt sosyo-ekonomik düzeye sahip öğrencilerin sadece 26,2'sinin her gün düzenli olarak kitap okudukları bulgusu bu araştırmanın sonuçlarını destekler niteliktedir. Benzer bir araştırma bulgusu da Karakoç (2005) tarafından lise birinci sınıf öğrencilerinin okuma ilgi ve

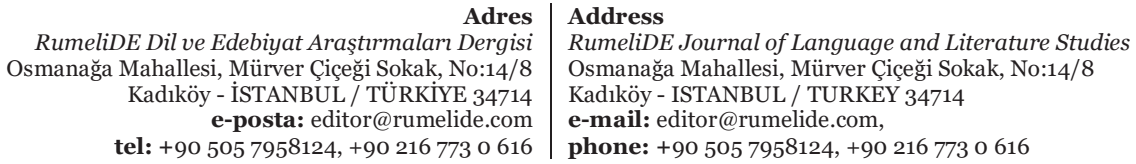


alışkanlıkları ile bunları etkileyen etmenleri belirlemek amacıyla yapılan çalısmada görülmektedir. $\mathrm{Bu}$ araştırma sonucuna göre, üst sosyo-ekonomik düzeye ait okulların öğrencilerinin okumaktan daha çok hoşlandıkları görülmüştür. Son bir yıl içinde hiç kitap okumayanların ya da en son ne zaman bir kitapçıya gittiğini hatırlamayanların oranı ise alt sosyo-ekonomik düzeyde diğerlerine göre daha yüksek çıkmıştır. Ayrıca hiç kitap okumadığı belirten öğrencilerin tamamının alt sosyo-ekonomik düzeyde oldukları bulunmuştur.

Türkçe öğretmenlerin görüşlerine göre, öğrencilerinin okuma alışkanlığına sahip olmalarının önünde engel olan unsurların araştıııldığı üçüncü temanın sonuçlarına bakıldığında, katılımcı öğretmenlerin en fazla televizyon izleme ve teknolojik iletişim araçlarını okuma alışkanlığına engel unsurlar olarak gördükleri belirlenmiştir. Aksaçlığlu ve Yllmaz (2007)'ın ilköğretim beşinci sınıf öğrencilerinin televizyon izlemeleri ve bilgisayar kullanmalarının okuma alıskanlıkları üzerindeki etkisini araştırdıkları çalışmada, katılımcı öğrencilerin bilgisayar kullanmayı ve televizyon izlemeyi kitap okumaya göre daha çok tercih ettikleri ve daha az televizyon izleyen, bilgisayar ile vakit geçiren öğrencilerin okuma saatlerinin diğer öğrencilere göre fazla olduğu sonucuna ulaşmışlardır. Temizyürek, Çolakoğlu ve Coşkun (2013), ortaöğretim dokuzuncu sınıf öğrencilerinin okuma alışkanlıkları ile okul türü ve cinsiyet değişkenleri arasındaki ilişkiyi belirlemeyi amaçladıkları çalışmada, lise öğrencilerinin televizyon izleme ve bilgisayar kullanma davranışlarının tüm öğrencilerin kitap okumalarını engelleyen ortak faktörler olduğunu ortaya koymuşlardır. İşcan, Arıkan ve Küçükaydın (2013)'ın, ortaokul öğrencilerinin kitap okumalarına engel olan durumlar olarak \%23,5'inin televizyonu, \%4'ünün bilgisayarı, \%6'sının arkadaşlarını; Acıyan (2008), ortaöğretim öğrencilerinin önemli bir bölümünün kitap okumayı sevmeme nedeni olarak, televizyon izlemeyi ve internette dolaşmayı (\% 41.9) gösterdiklerini tespit etmişlerdir. Arı ve Demir (2013)'in eğitim fakültesi öğrencileriyle yapmış oldukları çalışmada, katılımcı öğrencilerin, kitap okumaya engel olarak \%32'sinin televizyon izleme ya da interneti, \%28'inin ders çalışmalarını, \%18'inin kitapların pahalı olmasını, \%9.7 ‘sinin kitap okumayı sevmediklerini, \%7.6'sının istedikleri kitaplara kolayca ulaşabilecek ortamda olmayışlarını, \%4.7'sinin ise ekonomik durumları ifade ettikleri ortaya konmuştur. Duran ve Sezgin (2012) de ilköğretim 4 ve 5. sınıf öğrencilerinin boş zamanlarını televizyon seyrederek, bilgisayarda/ internette oyun oynayarak geçirdikleri sonucuna ulaşmışlardır. Bu sonuçlar, öğrencilerin kitap okuma önündeki en büyük engellerin başında televizyon izleme ve bilgisayar/internet kullanımının geldiği gerçeğini ortaya koymaktadır. Dolayısıyla bu sonuçların, okuma alışkanlığına engel olarak kitle iletişim araçları ve televizyon izlemenin ilk sırada yer aldığı yönündeki mevcut araştırma bulgularını destekler mahiyette olduğu söylenebilir. Bu bağlamda, hangi kademede olursa olsun öğrencilerin televizyon izlemeye, bilgisayar /internet kullanımına günde ayırdıkları sürenin çok fazla olduğu, bilgisayarın öğrencilerin hayatlarında çok fazla yer edindiği ve bu durumun da öğrencilerin okuma alışkanlığını olumsuz etkilediği şeklinde bir çıkarım yapılabilir.

Alanda yapılan diğer çalışmalara bakıldığında; Aksoy ve Öztürk (2019), ilköğretim öğrencilerinin okuma alışkanlı̆̆ kazanma durumlarını, öğretmenlerinin ve kendilerinin görüşleri doğrultusunda belirlemeyi amaçladıkları çalışmada, öğrenciler okumalarını engelleyen etmenler olarak; öncelikle ilgilerini çeken kitap, dergi vb. bulamamayı $(\% 40,5)$, televizyon izlemeyi $(\% 31,0)$, bilgisayar veya internetteki oyunları $(\% 30,6)$; ev ödevlerinin yoğunluğunu (\%29,0), okuma materyali eksikliğini $(\% 26,2)$, okumayı sıkıcı bulmayı $(\% 20,6)$ ve arkadaşlarında okuma alışkanlığının olmayışını $(\% 18,7)$ göstermişlerdir. Yalman, Özkan ve Kutluca (2013) tarafından eğitim fakültesi öğrencileriyle yapılan araştırmada, kitap okumaya engel olarak öğrencilerin \%52.72'sinin derslerin yoğunluğunu, \%12.73 ‘ünün bilgisayarı ve yine aynı oranda öğrencinin televizyon izlemeyi ifade ettikleri sonucuna ulaşılmıştır. Davarcı (2013) tarafından ilköğretim okullarındaki 8.sınıf öğrencilerinin kitap okuma alışkanlığı ile bilgisayar-internet kullanımı arasındaki ilişkinin değerlendirilmesi amacıyla yapılan çalışma

Adres | Address

RumeliDE Dil ve Edebiyat Araştırmaları Dergisi $\quad$ RumeliDE Journal of Language and Literature Studies

Osmanağa Mahallesi, Mürver Çiçeği Sokak, No:14/8 $\quad$ Osmanağa Mahallesi, Mürver Çiçeği Sokak, No:14/8

Kadıköy - İSTANBUL / TÜRKIYE 34714 Kadıköy - ISTANBUL / TURKEY 34714

e-posta: editor@rumelide.com e-mail: editor@rumelide.com,

tel: +90 5057958124, +902167730616 phone: +90 5057958124, +90 2167730616 
sonuçlarına göre, öğrenciler okumalarını engelleyen en önemli etken olarak ilk sırada derslerin yoğunluğunu (\%31,5), ikinci olarak bilgisayar/ interneti (\%15) ve üçüncü olarak da televizyonu $(\% 14,9)$ göstermişlerdir. Karakoç (2005), yeterince kitap okumayan öğrencilerin derslerden vakit bulamadığı için veya televizyon engeline takıldı ̆̆ı için kitap okuyamadığını saptamıştır. Aynı şekilde Güngör (2009), öğrencilerin kitap okumasına engel olan en büyük etkenin derslerin yoğunluğu (\% 36.5) olmasının yanı sıra televizyon izlemelerinin de olumsuz bir etken olduğunu; Bayis (2010), öğrencilerin kitap okumalarına en büyük engelin derslerinin yoğunluğu olduğunu belirlemişlerdir. Sarpkaya ve Kesici (2014), ilköğretim ve ortaöğretim öğrencilerinin yeterli kitap okumamalarının en önemli nedeni olarak dersleri, SBS, LYS gibi sınavları, kitap satın alma zorluğunu, sonrasında da kitap okuma alışkanlı̆̆ının olmayışını ve televizyon izlemeyi gösterdiklerini bulmuşlardır. Saracaloğlu, Karasakaloğlu ve Aslantürk (2010) tarafından yapılan okuma alışkanlığına ilişkin araştırmada ise; katılımcı öğrenciler yeterince kitap okumama nedeni olarak başta kitap fiyatlarının yüksek olmasını, ardından derslerden zaman bulamama ve yorgun olmayı göstermişlerdir. Şahin (2009) de, öğrencilerin kitap okuyamama sebepleri ile sosyo-ekonomik düzeyleri arasında yüksek düzeyde bir ilişki bulmuş ve kitapların pahalı olması sebebiyle okuyamadığını söyleyen 100 öğrenciden 75'inin alt sosyo- ekonomik düzeyde olduğu sonucuna ulaşmıştır.

Türkçe öğretmenlerinin, öğrencilerin okuma alışkanlığı kazanmasında etkili olan unsurların neler olduğuna yönelik görüşleri incelendiğinde; Türkçe öğretmenleri tarafından ortaokul öğrencilerinin okuma alışkanlığı kazanmasında etkili olan unsurlar olarak çoğunlukla aile, öğretmen ve arkadaşların dile getirildiği sonucuna ulaşılmıştır. Bu her üç unsurun rol model alt teması altında ve öğrenciye rol model olmaları yönüyle öğretmen görüşlerinde ön plana çlkmıştır. Bu sonuç, Deniz (2015) tarafında yapılan, ortaokul öğrencilerinin okuma alışkanlıklarının tespit edilmesine yönelik çalışmada elde edilen ortaokul öğrencilerinin kitap okumalarında en çok ailelerinden (\%36) sonra sırasıyla öğretmenlerinden (\%25), arkadaşlarından (\%19,9) etkilendikleri; Balcı (2009)'nın ailelerinin çocuklarının okuma alışkanlığında en etkili unsur olduğu ve Bayis (2010)'in, öğrencilerin okumasında anne ve babalarının, öğretmenlerinin ve yakın çevrenin etkili olduğu yönündeki bulgularıyla paralellik taşımaktadır. Aynı şekilde Acıyan (2008), anne ve babası çok okuyan öğrencilerin kitap okumayı daha çok sevdiğini ve dolayısıyla okuma alışkanlığına sahip anne ve babaların çocuklarının okuma alışkanlığının yüksek olduğunu belirlemiştir. Bu sonuçları teyit eden Suna (2006), ilköğretim öğrencilerinin okuma ilgi ve alışkanlıklarını etkileyen etmenleri incelediği çalışmasında, anne ve babanın okumak için zaman ayırmalarının; ailenin kitap satın almada çocuğun görüş ve tercihine önem vermesinin; anne veya babanın çocuğa sesli olarak kitap okumasının; evde kitap sohbetleri yapılmasının; çocuğa kitap hediye edilmesinin; çocuğun ailesiyle okuma saatinin olmasının; evde bir kitaplığının olmasının ve ailesiyle kütüphane, kitap fuarı gibi ziyaretleri yapmasının çocuğun okuma alışkanlı̆̆ına olumlu yönde etkisi olduğuna yer vermektedir. Bu bağlamda Dökmen (1994: 20-21), çocukların ve gençlerin okuma sevgisi ve alışkanlığ kazanmasında model yoluyla öğrenme boyutunda anne ve babanın rolünü değerlendirmektedir. Bu öğrenme ilkesi doğrultusunda öğrencilerin okuma alıskanlığı kazanmasında çocuğa model ve örnek olma vasfiyla, öncelikli ve en önemli unsur ailedir, denilebilir. Türkçe öğretmenlerinin görüşlerine göre, öğrencilerin okuma alışkanlığı kazanmasında rol model olma yönüyle etkili olan diğer unsur öğretmenlerdir. Güngör (2009)'ün öğrencilerin kitap okumalarında ilk sırada öğretmenlerinin (\%68.7) olmak üzere, annelerinin (\%41.9), babalarının ( \%46.2) ve "tamamen" derecesinde etkili olduğunu; Sarpkaya ve Kesici (2014), ilköğretim ve ortaöğretim öğrencilerinin okuma ve yazma alışkanlığını betimlemeye yönelik yaptıkları çalışmada, öğrenciler okuma alışkanlığında en çok öğretmenlerinden daha sonra annelerinden ve üçüncü sırada babalarından etkilendiklerini; Temizyürek, Çolakoğlu ve Coşkun (2013) yapmış oldukları araştırmada, öğrencilerin okumaya teşvik etmede, öğretmenin kitap okuyup kendi okuduğu kitapları öğrencilere anlatmasının Anadolu lisesi

Adres $\mid$ Address

RumeliDE Dil ve Edebiyat Araşttrmaları Dergisi Osmanağa Mahallesi, Mürver Çiçeği Sokak, No:14/8 Kadıköy - İSTANBUL / TÜRKIYE 34714 tel: +90 $5057958124,+902167730616$

RumeliDE Journal of Language and Literature Studies

Osmanağa Mahallesi, Mürver Çiçeği Sokak, No:14/8

Kadıköy - ISTANBUL / TURKEY 34714

e-mail: editor@rumelide.com,

phone: +90 $5057958124,+902167730616$ 
öğrencilerine $(\% 3,8)$ kiyasla teknik ve endüstri teknik lisesi öğrencilerinde $(\% 10,1)$ daha etkili olduğunu ortaya koymaktadırlar. Araştırmada Türkçe öğretmenleri, öğrencilerin okuma alışkanlığını en çok etkileyen diğer bir unsuru "Farkındalık oluşturma" alt temasında yer alan "evde okuma saatleri” ile ifade etmişlerdir. Öğretmenlere göre, evde ve okulda yapılan bu ve benzeri etkinlikler ile öğrencilerin teşvik ve desteklenmesinin onlarda okumaya yönelik farkındalık oluşturmakta ve bu unsurlar öğrenciler okuma alışkanlı̆̆ı kazanmasında etkili olmaktadır. Bu minvalde, Suna (2006), sınıfta okuma saatinin yapılmasının, öğrencinin sınıf kitaplığını aktif kullanmasını, öğretmenin okumaya yönlendirmesinin; öğretmenin sınıfta kitap, dergi, vb. tanıtımını yapmasının; öğrencinin öğretmeniyle kütüphane, kitap fuarı, vb. ziyaretleri yapmasının; arkadaşları ile kitap kritiği ve değiş tokuş yapmasının öğrencilerin okuma alışkanlık düzeylerini olumlu yönde etkilemekte olduğunu belirtmektedir.

Araştırmanın beşinci teması olan “Okuma Alışkanlığının Akademik Başarıya Etkisi”"ne ilişkin sonuçlara bakıldığında, araştırmaya katılan Türkçe öğretmenlerinin tümü, ortaokul öğrencilerinin okuma alışkanlıkları ile akademik başarıları arasında doğru orantılı bir ilişki olduğu yönünde görüş bildirmişlerdir. Buna ilaven, Türkçe öğretmelerinin yüksek oranda okuma alışkanlığıyla öğrencilerinin akademik başarılarının arttığı ve bilişsel becerilerinin geliştiği görüşünde oldukları tespit edilmiştir. Bu sonuç, Güngör (2009)'ün öğrencilerin kitap okuma alışkanlıklarının akademik başarı düzeyleri düştükçe azaldığı; Aksoy (2017)'un TEOG sınavı ile ortaokul öğrencilerinin okuma alışkanlığı arasında anlamlı bir ilişki olup olmadığını ortaya koyma amacıyla yaptıkları çalışmada ulaşılan TEOG sınavı kapsamında bulunan altı dersin test puanlarıyla öğrencilerin okuma alışkanlı̆̆ı arasında olumlu yönde anlamlı ilişki olduğu ve Berkant ve Tüzer (2017)'in, sekizinci sınıf öğrencilerinin okuma alışkanlıklarını ve sayısal ders başarılarını çeşitli değişkenler açısından inceledikleri araştırmada, okuma alışkanlıkları ile sayısal ders başarısı arasında pozitif yönlü anlamlı bir ilişki olduğu sonuçlarıyla benzerlik göstermektedir. Bu çalışmalara ilaven; Kara (2019). Sınıf Öğretmenliği bölümü öğrencilerinin okuma alışkanlıklarında akademik başarının etkili olduğu sonucuna ulaşırken; Acıyan (2008), ortaöğretim öğrencilerinin okuma alışkanlıkları ile akademik başarısı arasındaki ilişkiyi ortaya koyduğu çalışmasında, katılımcı öğrencilerin çoğunluğunun ( \% 57.2) okumanın başarılarını artırdığı görüşünde olduklarını belirlemiştir. Yılmaz (2012), ilköğretim 8. sınıf öğrencilerinin kitap okuma alışkanlıkları ile okul başarıları arasındaki ilişki düzeyini ve niteliğini belirlemeyi amaçladığı çalışmasında, öğrencilerin kitap okuma sıklığı arttıkça 6 . ve 7. sinıf not ortalamalarının da yükselmekte olduğunu ve 6 . sınıf öğrencilerinin okuma alışkanlıklarının okul başarılarını artırdığını düşündükleri bulgusuna yer vermektedir.

Katılımcı Türkçe öğretmenlerinin, ortaokul öğrencilerine okuma alışkanlığı kazandırmaya yönelik önerilerinin neler olduğunun incelendiği "Okuma Alışkanlığını Kazandırmaya Yönelik Öneriler" temasına ait sonuçlara bakıldığında, Türkçe öğretmenlerinin en fazla okullara sonrasında öğretmenlere ve ailelere yönelik önerilerde bulundukları belirlenmiştir. Bu durum araştırmaya katılan Türkçe öğretmenlerinin, öğrencilerin okuma alışkanlı̆̆ı kazanmasında sorumluluk ve görevi en çok okullarda gördükleri şeklinde yorumlanabilir. Okullar öğrencilerin öğrenme merkezleri olarak temel birçok becerinin yanında okuma alışkanlığı becerisinin kahıcı hale gelmesini sağlamaya yönelik faaliyetlerin de odağında bulunmaktadır. Bu nedenle okulların sahip olduğu özellikle maddi ve fiziksel imkânları çerçevesinde öğrencilere sunacağı firsatlar daha fazla ve daha çeşitli olmaktadır. Bu bağlamda okullarda başlatılan okuma alışkanlığı kazandırma çalışmaları sınıfta öğretmenler, evde aile bireyleri tarafından desteklenip sürdürüldükçe kalıcı ve etkili hale gelecektir. Bu nedenle öğretmenlerin ve ebeveynlerin çocuğa göstereceği ilgi, hassasiyet ve duyarlılı̆̆ı belirleyici olduğu söylenebilir. Ayrıca çocukların okuma alışkanlığı kazanması için öğretmen ile ailenin işbirliği içinde olması bir zorunluluk olmaktadır.

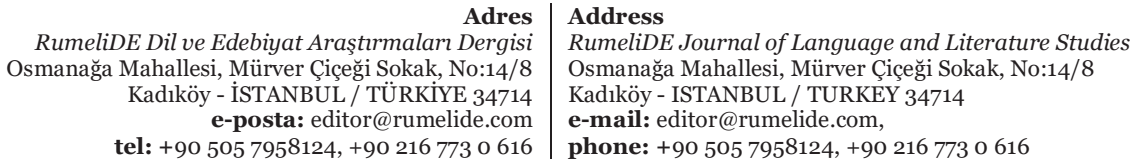




\section{5. Öneriler}

Araştırmanın bulgularına dayalı olarak aşağıda şu önerilere yer verilmiştir.

1. Okullar kendilerine özgü, sahip oldukları çevresel, sosyal, ekonomik ve fiziksel imkânları ölçüsünde okuma etkinlikleri düzenlenmelidir. Bu doğrultuda okullar öğretmen, veli, öğrenci işbirliğinin merkezi konumunda yer almalıdır.

2. İl ve ilçelerde resmi kurum ve kuruluşların, sivil toplum örgütlerinin teşvik edip katkıda bulunacağı kitap toplama kampanyaları oluşturulmalıdır. Toplanan bu kitaplar öğrencilere ulaştırılarak öğrencilerin kitaba erişimi ücretsiz ve kolay hale getirilmelidir.

3. Öğrenciler rol model olan öğretmenler, sinfflarında keyifli, eğlenceli ve öğrencilerin hoşlanacağı okuma etkinlikleri düzenlemelidir. Böylece öğrencilerin okumaya karşı olumlu bir tutum içinde olmaları sağlanmalıdır.

4. Öğretmenler, özelde Türkçe öğretmenleri, dersin içeriğine ve özelliğine uygun olarak konuyu kitapların kahramanları/ konusuyla ilişkilendirerek işleyebilirler.

5. Anne ve babanın çocuğun okumaya yönelmesindeki etkisi sık sık gündeme getirilmeli, öğrencilerin okuma alışkanlığını geliştirmek için ailenin tüm fertlerinin ve özellikle de annenin çağdaş anlamda okuryazarlık kazanması sağlanmalıdır.

6. Resmi kurum ve kuruluşlar ile sivil örgütlerince ebeveynde okuma bilinci oluşturmaya yönelik cazip ve ilgi çekici aile eğitimi/ seminerleri düzenlenmelidir.

7. Tüm branş bazında öğretmenlere, öğrencilerine etkili okuma yöntem ve tekniklerini öğretmelerini sağlayacak eğitimler verilmelidir.

8. Okullarda rehber öğretmenler öncülüğünde televizyon izlemeye ve teknolojik araçların kullanımına yönelik öğrenci ve aile bilinçlendirme eğitimleri düzenlenmelidir.

9. Televizyon ve diğer iletişim yayın organlarında öğrencileri ve ailelerini okumaya teşvik eden, özendiren içeriklere, kitap tanıtım reklamlarına ve tanıtım filmlerine daha sıklıkla yer verilmeli.

10. İleriye dönük çalışmalarda ilkokul ve ortaokul kademelerindeki öğrencilere okuma alışkanlığının kazandırılmasına yönelik nitel ve nicel verilerin kullanılacağı Karma yöntemli araştırmalar yapılabilir.

\section{Kaynakça}

Acıyan, A. (2008). Ortaöğretim öğrencilerinin okuma alışkanlıkları ve akademik başarı düzeyi arasındaki ilişki, Yayınlanmamış yüksek lisans tezi, Yeditepe Üniversitesi Sosyal Bilimler Enstitüsü, İstanbul.

Aksaçlığlu, A. ve Yılmaz, B. (2007). Öğrencilerin televizyon izlemeleri ve bilgisayar kullanmalarının okuma alıskanlıkları üzerine etkisi. Türk Kütüphaneciliği, 21(1), 3-28.

Aksoy, T. (2017). Okuma alışkanlığının Temel Eğitimden Ortaöğretime Geçiş (TEOG) Sınavına etkisi. Ana Dili Ĕ̆itimi Dergisi, 5(4), 571-588.

Aksoy, E. ve Öztürk, D. S. (2018). Öğrencilerdeki okuma alışkanlı̆̆ının öğretmen ve öğrenci görüşlerine göre belirlenmesi. Türkiye Sosyal Araştırmalar Dergisi, 22 (1), 143-184.

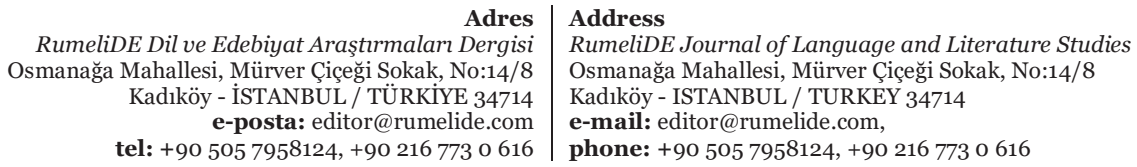


Alperen, N. (1990). Türkçe (Güzel Konuşma, Okuma ve Yazma ) Öğretim Rehberi. İstanbul: Milli Eğitim Bakanlı̆̆ı Yayınları.

Anish, C.A., \& Joseph, J. (2017). Reading habits of higher secondary schoolsStudents: A study. Imperial of Journal of Interdisplinary Research, 3 (5), 1939-1949.

Arı, E. ve Demir, M.K. (2013). İlköğretim bölümü öğretmen adaylarının kitap okuma alışkanlıklarının değerlendirilmesi. Ana Dili Ĕ̆itimi Dergisi, 1(1), 116-128.

Arıcı, A. F. (2015). Türkçe öğretmenleri / öğretmen adayları ne okumalı?-bir "okuma listesi” önerisi. Hacettepe Üniversitesi Eğitim Fakültesi Dergisi, 30 (3) , 1-15.

Balcı, A. (2009). İlköğretim 8. sınıf öğrencilerinin okuma alışkanlık ve ilgileri üzerine bir araştırma. Yayımlanmamış doktora tezi, Gazi Üniversitesi, Ankara.

Bamberger, R., (1975). Promoting the reading habit. Paris: Unesco Press.

Batur, Z., Erkek, G., Kaplan, K. \& Ercan, E. (2017). Türkçe eğitimi ve yabancı dil olarak İngilizce öğretiminde dört temel dil becerisinin edinimine ilişkin öğretmen görüşleri, Avrasya Dil Eğitimi ve Araştırmaları Dergisi, 1(1), 42-75.

Bayat, N., \& Çetinkaya, G. (2018). Ortaokul öğrencilerinin okuma alışkanlıkları ve tercihleri. İlköğretim Online, 17(2), 984-1001.

Bayis, S. (2010). 4. 5. 6. ve 7. sınıf ilköğretim öğrencilerinin okuma ve kütüphane kullanım alışkanlıklarının incelenmesi. Yayımlanmamış yüksek lisans tezi, Hacettepe Üniversitesi Hacettepe Üniversitesi Sağlık Bilimleri Enstitüsü, Ankara.

Bayram, O. (1990). İlkokul çağı çocuklarının okuma alışkanlığı ve Yenimahalle İlçe Halk Kütüphanesi Gezici Kütüphane Hizmeti. Yayımlanmamış Yüksek Lisans Tezi. Hacettepe Üniversitesi, Ankara.

Bekar, Ü. (2005). İlköğretim beşinci sınıf öğrencilerinin okuma alışkanlığı kazanmalarında ailelerin rolü: Kastamonu ili örneği, Yayımlanmamış yüksek lisans tezi. Gazi Üniversitesi, Ankara.

Belet Boyacı, Ş. D. ve Güner Özer, M. (2019). Öğrenmenin geleceği: 21. Yüzyıl becerileri perspektifiyle Türkçe dersi öğretim programları. Anadolu Journal of Educational Sciences International, 9(2), 708-738.

Berkant, H. G. \& Tüzer, A. (2017). Sekizinci sınıf öğrencilerinin okuma alışkanlıkları ve sayısal ders başarılarının çeşitli değişkenlere göre incelenmesi. Kahramanmaraş Sütçü İmam Üniversitesi Sosyal Bilimler Dergisi, 14 (2) , 171-190.

Büyüköztürk, Ş., Çakmak-Kılıç, E. vd. (2012). Bilimsel araştırma yöntemleri. Ankara: Pegem Akademi Yayınları.

Can, R. , Türkyılmaz, M. \& Karadeniz, A. (2010). Ergenlik dönemi öğrencilerinin okuma alışkanlıkları. Ahi Evran Üniversitesi Kırşehir Ë̆itim Fakültesi Dergisi, 11 (3) , 1-21 .

Christensen, L. B., Johnson, R. B., \& Turner, L. A. (2015). Nitel ve karma yöntem araştırmaları (Çev. Ahmet Aypay). Ankara: Anı. Yayıncılı.

Creswell, J. W. (2017). Nitel araştırmacılar için 30 temel beceri (Çev. Hasan Özcan). Ankara: Anı. Yayıncılık.

M. Sever, (Çev.). A. Aypay (Ed). Araştırma yöntemleri desen ve analiz içinde (ss. 400-433). Ankara: Anı Yayıncilık.

Çakmak, T. \& Yılmaz, B. (2009). Okul öncesi dönem çocuklarının okuma alışkanlığına hazırlık durumları üzerine bir araştırma: Hacettepe Üniversitesi Beytepe Anaokulu Örneği. Türk Kütüphaneciliği, 23,3,489-50.

Çelik, H., Genç, K., \& Gencer, R. (2017). Sosyal bilgiler öğretmen adaylarının okuma kültürleri üzerine nitel bir araştırma. Kafkas Üniversitesi Sosyal Bilimler Enstitüsü Dergisi, (20), 397-413.

Çelik, Y. (2020). Okuma alışkanlığının kazandırılmasına ilişkin öğretmen görüşlerinin incelenmesi. Anemon Muş Alparslan Üniversitesi Sosyal Bilimler Dergisi, 8 (4), 1027-1037.

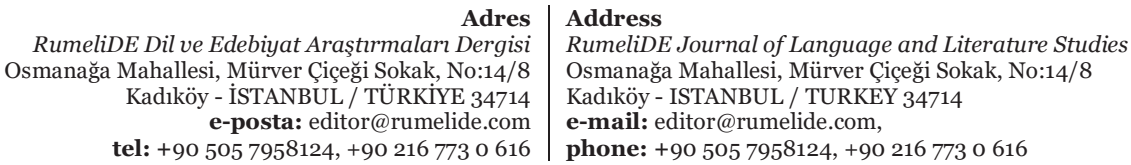


Doğan, B. (2014). Öğretmen adaylarının kitap okumanın önemine ilişkin gerekçeler. Bilgi Dünyası, 15 (1) $159-175$.

Davarcı, N. (2013). İlköğretim 8. sınıf öğrencilerinin kitap okuma alışkanlığı ile bilgisayar - internet kullanımı arasındaki ilişkinin değerlendirilmesi. Yayımlanmamış yüksek lisans tezi, Çukurova Üniversitesi Sosyal Bilimler Enstitüsü, Adana.

Deniz, E. (2015). Ortaokul öğrencilerinin kitap okuma alışkanlıkları. Okuma Yazma Eğitimi Araştırmaları, 3 (2), 46-64.

Deniz, A. (2017). Ortaokul öğrencilerin okuma alışkanlığının geliştirilmesi üzerine Türkçe öğretmenlerinin görüşleri. Yayımlanmamış yüksek lisans tezi, Adıyaman Üniversitesi Sosyal Bilimler Enstitüsü, Adıyaman.

Doğan, B., Ateş, S., Çermik, H. ve Yıldırım, K. (2018).Okuma göstergeleri zayıf! İyileştirmek için bir adım atalım. TAY Journal, 2(1), 46-62.

Duran, E. ve Sezgin, B. (2012). İlköğretim 4 ve 5. sınıf öğrencilerinin okuma alışkanlıklarının ve ilgilerinin belirlenmesi. Turkish Studies 7(4) 1449-1462.

Durukan, E. \& Arslan, N. (2018). Türkçe dersi öğretim programlarında okuma eğitimi. S.Alyılmaz ve B.Ürün-Karahan (Ed.). Okuma eğitimi içinde (s. 157-172), Ankara. Anı Yayıncılık.

Ekiz, D. (2017). Bilimsel araştırma yöntemleri. Ankara: Anı Yayıncılık.

Emin, T., (2003). Alımlama estetiği ve edebiyat öğretimi. Erişim Tarihi: o7 Eylül 2021.http://web.deu.edu.tr/ilyas/genc/dosyalar/alimlama.pdf

Farran, L. K., (2010).The Relationship between Language and Reading in Bilingual English-Arabic Children. Unpublished doctoral dissertation, Georgia State University, Atlanta.

Güneş, F. (2016). Kâğıttan Ekrana Okuma Alanındaki Gelişmeler, Bartın Üniversitesi Eğitim Fakültesi Dergisi / Bartın Unversity Journal of Faculty of Education, 5(1),1-18.

Güney, N., Aytan, T., Kaygana M. \& Şahin, E.Y. (2014). Dokuzuncu sınıf öğrencilerinin ｏkuduğu kitap sayısı ile akademik başarıları arasındaki ilişki üzerine bir değerlendirme. Süleyman Demirel Üniversitesi Sosyal Bilimler Enstitüsü Dergisi, 1 (19), 151-164.

Gündoğdu, C., Barata, B. ve Çelebi, E. (2016). 15-29 yaş arası gençlerin kitap okuma alışkanlıklarının incelenmesi: Elazı̆ il örneği. Ĕ̆itim ve Öğretim Araştırmaları Dergisi, 5 (2), 36-42.

Güngör, E. (2009). İlköğretim 5. sınıf öğrencilerinin kitap okuma alışkanlığı ile Türkçe dersi akademik başarıları arasındaki ilişkinin incelenmesi. Yayımlanmamış yüksek lisans tezi, Çukurova Üniversitesi, Sosyal Bilimler Enstitüsü, Adana.

İşcan, A., Arıkan, İ.B. \& Küçükaydın, M.A. (2013). İlköğretim ikinci kademe öğrencilerin kitap okuma alışkanlıkları ve okumaya ilişkin tutumları. Uluslararası Avrasya Sosyal Bilimler Dergisi, 4 (11), 3-28.

Johnson, A.P. (2008). Teaching reading and writing: A guidebook for tutoring and remediating students New York: Rowman and Littlefield Education.

Kantaş, Z. (2013). Gençlik dönemi okuma (15-18 yaş). A. Okur (Ed.). Yaşam boyu okuma eğitimi içinde.(s.185 - 222). Ankara: Pegem Akademi.

Karadayı, F. (2019). Bilim ve sanat merkezlerine devam eden 5, 6, 7 ve 8. sinıf öğrencilerinin okuma alışkanlık ve eğilimlerinin belirlenmesi. Yayımlanmamış yüksek lisans tezi, Necmettin Erbakan Üniversitesi Eğitim Bilimleri Enstitüsü, Konya.

Kara, M. (2019). Sınıf öğretmeni adaylarının okuma alışkanlığı ve kütüphane kullanımı üzerine bir inceleme. Yayımlanmamış yüksek lisans tezi, Trakya Üniversitesi Sosyal Bilimler Enstitüsü. Edirne.

Karatay, H. , Külah, E. \& Kaya, S. (2020). Okuma alışkanlığını geliştirme yöntem, teknik ve modelleri . Okuma Yazma Eğitimi Araştırmaları, 8 (1) , 89-107.

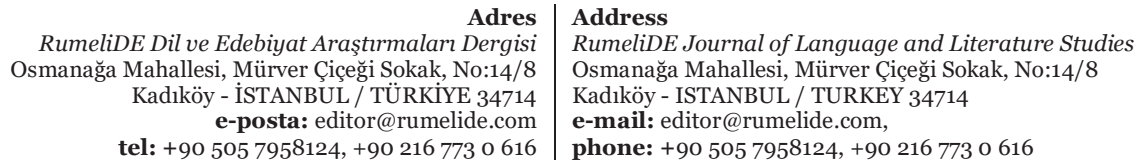


Kaynar, İ. (2007). Ortaöğretim öğrencilerinin okuma alışkanlığı ve iletişim becerileri. Yayımlanmamış yüksek lisans tezi, Yeditepe Üniversitesi Sosyal Bilimler Enstitüsü, İstanbul.

Keleş, Ö. (2006). İlköğretim 4. ve 5. sınıf öğrencilerinde kitap okuma alışkanlığının incelenmesi. Yayınlanmamış yüksek lisans tezi, Gazi Üniversitesi Eğitim Bilimleri Enstitüsü, Ankara.

Le, T.T. H., Tran, T., Trinh, T. P. T., Nguyen, C. T., Nguyen, T. P. T., Vuong, T.T., Vu, T. H., Bui, D.Q., Vuong, H. M., Hoang, P.H., Nguyen, M. H., Ho, M.T., \& Vuong, Q,H., (2019). Reading habits, socioeconomic conditions, occupational aspiration and academic achievement in vietnamese junior high school students. Sustainability, 11, 5113, 1- 29.

Mete, G. (2012). İlköğretim 8. sınıf öğrencilerinin okuma alışkanlığı üzerine bir araştırma (Malatya ili örneği). Dil ve Edebiyat Ĕ̆itimi Dergisi, 1(1), 43-66.

Miles, M, B., \& Huberman, A. M. (1994). Qualitative data analysis: An expanded Sourcebook. (2nd ed). Thousand Oaks, CA: Sage.

Mut, G. \& Gelişli, Y. (2021). Ortaokul 8. sınıf öğrencilerinin okuma alışkanlığının oluşmasında etkili olan faktörlere ilişkin görüşleri. Muallim Rıfat Eğitim Fakültesi Dergisi (MREFD), 3(1), 92-113.

Millî Eğitim Bakanlığı [MEB] (2006). İlköğretim Türkçe Dersi (6,7,8.Sınıflar) Öğretim Programı. Ankara: Millî Eğitim Bakanlığı Yayınları. Erişim Tarihi:07 Ekim 2021. meb_iys_dosyalar/25/10/711870/dosyalar/2016_10/

Milli Eğitim Bakanlığı [MEB]. (2019a).Türkçe Dersi Öğretim Programı (İlkokul ve

Ortaokul 1, 2, 3, 4, 5, 6, 7 ve 8. Sinıflar). Ankara. Erişim Tarihi:10 Eylül 2021 http://mufredat.meb.gov.tr/Dosyalar/2019571639225302

Noor, N. M. (2011). Readıng habits and preferences of efl post graduates: A case study. Indonesian Journal of Applied Linguistics, 1 (1), 1-9.

Okur, A. (2013). Yaşam boyu okuma için okuma öğretimi. A. Okur (Ed.), Yaşam boyu okuma eğitimi içinde (s.1-40). Ankara: Pegem Akademi.

Özbay, M. \& Bahar, M. A. (2012). İleri okur ve üstbiliş eğitimi. Uluslararası Türkçe Edebiyat Kültür Ĕ̆itim (TEKE) Dergisi, 1 (1) , 158-177 .

Özden, M. (2018). Niçin okumuyoruz? Tarih Okulu Dergisi (TOD) 11 (37), 299-313.

Rosli, N.A., Razali, N.F., Zamil, Z.U.A., Noor, S.N.F.M. \& Baharuddin, M.F. (2017). The determination of reading habits among students: a concept. International Journal of Academic Research in Business and Social Sciences. 7 (12). 791-798.

Saracaloğlu, A.S., Karasakaloğlu, N. ve Aslantürk, E. (2010). Sinıf öğretmeni adaylarının okuma ilgi ve alışkanlıklarının karşılaştırılması (Adnan Menderes ve Uludağ üniversiteleri örneği), Ç.Ü. Sosyal Bilimler Enstitüsü Dergisi, 19(3), 457-480.

Sayır, M.F. (2018). Okuma eğitimi ile ilgili temel kavramlar. O. Sevim ve Y. Söylemez (Ed.). Okuma eğitimi içinde, (s.1-9). Ankara: Nobel Yayınları.

Sever, S. (2003). Türkçe Öğretiminde Yeni Yapılanma Çalışmaları. Türklük Bilimi Araştırmaları (TÜBAR), 13 (13), 27-38.

Sheeba, S. ve Mohd, H. A. (2018). Teaching reading : Goals and techniques. Mohd, Shakir

(Ed.), In Emerging trends in education (pp. 1-12). New Delhi: New Delhi Publisher.

Sivasubramanian, G. \& Gomathi, P. (2019). A study on reading habits among higher secondary school students in Salem, Tamil Nadu India. Library Philosophy and Practice (e-journal). 2576.1-16.

Suhana, A \& Haryudin, A. (2017). The effects of readıng habit towards students' readıng comprehension at private senıor high schoolın Purwakarta. Eltın Journal , 5 (2), 57-70.

Suna, Ç, (2006). İlköğretim öğrencilerinin okuma ilgi ve alışkanlıklarını etkileyen etmenlerin analitik olarak incelenmesi ve değerlendirilmesi. Yayımlanmamış yüksek lisans tezi. Anadolu Üniversitesi, Eskişehir.

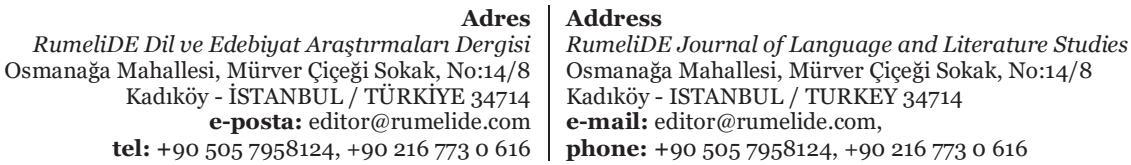


Şahin, A., Sevim, O., Gücüyeter, B. ve Şahin, E. (2009). Öğretmen adaylarının okuma durumları: Atatürk Üniversitesi örneği. Atatürk Üniversitesi Kâzım Karabekir Ĕ̆itim Fakültesi Dergisi. 19, 1-21.

Taş, H. (2018). İlkokul 4. sinıf öğrencilerinin okuma alışkanlıkları ve tercihleri üzerine bir değerlendirme. Uluslararası Türkçe Edebiyat Kültür Ĕ̆itim Dergisi, 7(3), 1947- 1975.

Taşkesenoğlu, L. (2013). Ortaöğretim Öğrencilerinin Okuma Alışkanlıkları Üzerine Bir İnceleme. Karadeniz Sosyal Bilimler Dergisi , 5 (9).

Ungan, S. (2008). Okuma alışkanlığımızın kültürel altyapısı. Gaziantep Üniversitesi Sosyal Bilimler Dergisi, 7(1), 218-228.

Ülger, D. K. (2015). Motivasyon ve model alma kavramlarının ilkokul dördüncü sınıf öğrencilerinin okuma alışkanlığına etkisi: Ankara örneği. Akademia Sosyal Bilimler Dergisi , (1) , 18-43 .

Yalman, M., Özkan, E. \& Kutluca, T. (2013). Eğitim fakültesi öğrencilerinin kitap okuma alışkanlıkları üzerine betimsel bir araştırma: Dicle Üniversitesi Örneği. Bilgi Dünyası. 14 (2), 291-305.

Yavaş, S. (2013). İlköğretim 4. ve 5. sınıf öğrencilerinin kitap okuma alışkanlıkları ile üst düzey düşünme becerileri arasındaki ilişkinin değerlendirilmesi. Yayımlanmamış Yüksek Lisans Tezi. Konya: Necmettin Erbakan Üniversitesi, Eğitim Bilimleri Enstitüsü.

Yengin Sarpkaya, P. \& Elitok Kesici, A. (2014). İlköğretim ve lise öğrencilerinin okuma ve yazma alışkanlıkları: aydın ili örneği. Milli Eğitim Dergisi , 44 (201) , 17-38 .

Yıldız, D. (2018). Okuma becerisine yönelik eğitim ortamları. O. Sevim ve Y. Söylemez (Ed.), Okuma eğitimi içinde (s. 179-193). Ankara: Nobel Yayıncılık.

Yıldırım, A. ve Şimşek, H. (2016). Sosyal bilimlerde nitel araştırma yöntemleri. Ankara: Seçkin Yayıncilı.

Yılmaz, B. (2012). Okuma alışkanlığının okuma başarısına etkisi: Ankara Keçiören Atapark İlköğretim Okulu öğrencileri üzerine bir araştırma. Ö. Külcü, T. Çakmak ve N. Özel. (Yay. haz). Prof. Dr. K. Gülbün Baydur'a Armağan içinde (s. 209-218). Ankara: Hacettepe Üniversitesi Bilgi ve Belge Yönetimi Bölümü.

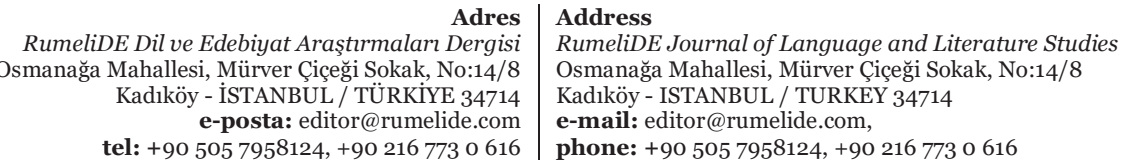

